\title{
Death near the shoreline, not life on land: Ordovician arthropod trackways in the Borrowdale Volcanic Group, UK
}

\author{
Anthony P. Shillito and Neil S. Davies
}

Department of Earth Sciences, University of Cambridge, Downing Street, Cambridge CB2 3EQ, UK

\begin{abstract}
The Borrowdale Volcanic Group of northern England hosts Late Ordovician arthropod trackways that are frequently cited as the earliest unequivocal evidence for animal life on land, and provides a key geological locality for our understanding of global myriapod evolution and terrestrialization. Original fieldwork at the trace fossil site has identified four additional bedding surfaces that yield 121 new trackways at the site (of a total 158 known individuals), and permit better sedimentological and paleoecological contextualization of the trackways. Contrary to published claims, none of the trackways occur in sandstones but are invariably preserved on bedding planes of dacitic tuffs. Trackway morphology comprises either short straight track segments with discernable footprint impressions (Diplichnites), long looping traces suggesting dragging and footprint amalgamation (Diplopodichnus), or transitional forms. Morphometric comparison of the Diplopodichnus with fossil and recent mortichnia (death traces) suggests they record immediate pre-mortem locomotion of dying myriapods, and modern analogue reveals mechanisms by which abundant volcanic ash within the environment would have elevated arthropod mortality rates. Sedimentary structures including wave ripples, bedding sags and detached large-scale ball-and-pillow structures, show that the tuffs were deposited subaqueously. One newly-discovered instance where trackways intermittently traverse $3-5 \mathrm{~cm}$ tracts of subaerially-exposed wave-ripple crestlines attests that the tracemakers were capable of surviving out of water over very short distances. However, the low diversity, semi-subaqueous ichnofauna has greater similarity with other Cambrian and Ordovician sites, recording pioneer tracemakers with limited tolerance of subaerial environments, than it does with the oldest preserved fully-terrestrial trace fossil communities from the Silurian and Devonian.
\end{abstract}

\section{TRACKWAYS OF THE BORROWDALE VOLCANIC GROUP}

The Borrowdale Volcanic Group (BVG) is a 6 km-thick Upper Ordovician (Sandbian-Katian) succession of volcanic and related rocks that crops out in Cumbria, NW England, and which accumulated in an arc setting associated with subduction of the lapetus Ocean (Barnes et al., 2006). Trace fossils were first discovered within the group by Mitchell (1956, p. 434), who reported "animal-tracks" on bedding planes at Lum Pot; a 150 m-long outcrop along the River Lickle, which exposes a near-continuous 25 m-thick stratigraphic section from the upper BVG (likely within its constituent Wallowbarrow Tuff Formation (Fig. 1; see Appendix)). The trace fossils were later identified as Diplichnites and Diplopodichnus by Johnson et al. (1994), who described them on the basis of 34 trackways on a $1.9 \mathrm{~m} 2$ bedding plane at Lum Pot and 3 trackways on the $0.1 \mathrm{~m} 2$ surface of a loose clast from Sour Milk Gill, $19 \mathrm{~km}$ north of the original locality. Johnson et al. (1994) documented that the trackways occurred in sandstone, which they interpreted as having been deposited in a freshwater lacustrine environment. Subsequently, this report of Late Ordovician, fully non-marine arthropod trackways has had substantial influence on studies concerning the evolution of life on land. The BVG trackways are widely cited as the oldest unequivocal 
ichnological evidence for established non-marine arthropod communities (e.g., Davies et al., 2010; Minter et al., 2016) and indirect evidence for the oldest terrestrial myriapods (e.g., Wilson, 2006).

\section{LITHOLOGY OF THE TRACKWAY HORIZONS}

In this study we have identified four new trackway-bearing bedding planes at Lum Pot (Surfaces A-D), bringing the total number of trackways recognized at the site to 158 . There is no evidence to support previous assertions that they were deposited in a non-marine environment, which were based in part on the incorrect identification of their host lithology as fine-, medium- or coarse-grained sandstone (Johnson et al., 1994) (see Appendix). In actuality the trackways at Lum Pot are invariably cast in very fine dacitic tuff (Fig. 2). The thickness of individual tuff beds is commonly hard to discern due to weathered outcrop. However, the substrate revealed as Surface C (Fig. 2E) consists of amalgamated 1 $\mathrm{cm}$-thick coarse-fine cycles, possibly recording discrete events, and elsewhere discrete tuff beds are recognized up to $30 \mathrm{~cm}$ thick. Locally the tuffs contain vesicular horizons (Fig. $2 \mathrm{C}$ ) and $<3 \mathrm{~cm}$-diameter clasts of pumice (or similar-sized weathered-out holes) (Fig. 2D) and petrographically each of the known trace fossil beds consists of a partially chloritized homogenous cryptocrystalline matrix with up to $30 \%$ opaque fragments (see Appendix). Isolated grains or more coarsely-crystalline bands permit the identification of subhedral alkali feldspar crystals (indicating a proximal source) and subhedral opaque oxide minerals (see Appendix), in addition to isolated lithic clasts, pumice, mica and calcite. There is a marked lack of (visible) quartz.

\section{ENVIRONMENTAL SETTING}

Johnson et al. (1994) considered the BVG trace fossils to be non-marine based on three lines of evidence: 1) At Sour Milk Gill, the loose block was found near bedrock outcrop of the Whorneyside Formation, which contains structures indicative of subaerial volcanism, and emergent volcanoclastic sedimentary substrates (Branney, 1991); 2) The $6 \mathrm{~km}$ BVG succession as a whole predominantly accumulated in non-marine environments (Branney, 1988) and contains few marine fossils; and 3) Modern isopods make trackways analogous to Diplichnites/Diplopodichnus in a drying mixture of very fine sand and clay.

The latter two lines of evidence are weak because the BVG is not necessarily exclusively non-marine (Branney, 1988), other Paleozoic clastic successions in the region can be poorly fossiliferous despite being deposited in marine settings (Rickards and Woodcock, 2005), and the Lum Pot trackways are preserved in materially-distinct ash and dust rather than sand and clay. Direct evidence for the trackways being non-marine rests on the Sour Milk Gill specimen having been derived from the local bedrock. However, it was recovered from the margin of a U-shaped valley, carved during Quaternary glaciations, and the local terrain is covered with extensive moraine, erratics and alluvium, the clasts of which consist of a range of regionally-derived lithologies (Wilson, 2004). As no in situ trace fossils are known from the Whorneyside Formation, despite concerted investigation and its good bedding plane exposure, the uncertain provenance of the loose block means it is unreliable as evidence for non-marine conditions.

The well-exposed Lum Pot section is more suited to confidently determining the tracemaker habitat. Here, a number of volcanic and sedimentary structures indicate that the trackway-bearing tuffs were deposited subaqueously: 1) Detached balls (Fig. 2J), imply emplacement onto a heated, fluidized wet substrate (Branney and Kokelaar, 2002); 2) Bifurcating wave ripples (Fig. 2B) attest to remobilization of 
ash within shallow water, and climbing ripples indicate sustained sediment input into water (Fig. 2F); 3) Bedding sags (Fig. 2H) form when ejecta impacts wet, but not dry, sediment (Fisher and Schmincke, 1984); and 4) The association of vesicles with convolute lamination (Fig. 2C,I), suggests that the ash was water-rich at the time of deposition (Fisher and Schmincke, 1984). Further circumstantial evidence includes the lack of diagnostically subaerial structures common in many parts of the BVG (Branney, 1988 ) and the tuff's conformable stratigraphy above the lower Dunnerdale Sandstone Formation, which is composed of turbidite sandstones (Johnson et al., 2001). There is no diagnostic evidence to determine if the water in which the tuffs were deposited was freshwater or saline.

Ash can be variably consolidated after deposition, affecting its material properties and thus its likelihood of being indented with trackways. The Lum Pot succession contains evidence that both firm (Fig. 2G, 3G) and semi-firm (Fig. 2A) (i.e., cohesive media), and unconsolidated (Fig. 2B) (i.e., granular media) substrates were traversed by the tracemakers (Fig. 3). Trackways are most common on cohesive substrates, but on unconsolidated, wave-rippled substrates, they are preserved only on ripple crests, implying material differences to ripple troughs (Fig. 3B-C, Appendix). This was most likely due to standing water, with moisture impeding trackway emplacement when substrates were composed of granular media, and provides the first direct evidence from the BVG that the tracemakers were adapted to traverse subaerial surfaces for short distances. Conversely, where trackways are seen on firm and semi-firm substrates of cohesive media, trackways are pervasive across substrate topography (Fig. 3D-E) and must have been imparted when cohesive sediment was wholly wet or damp, so that it could plastically deform and retain footprint indents.

. The null hypothesis is that the trace fossils were made by subaqueously-dwelling animals, because: (1) all known trackways were emplaced onto subaqueously-deposited ash-fall substrates; (2) no trackways are known from demonstrably subaerial Borrowdale facies; and (3) evidence for established subaerial animal communities elsewhere in the world is lacking before the Silurian (Minter et al., 2016).

\section{TRACEMAKER BEHAVIOR}

The trackways at Lum Pot consist exclusively of Diplichnites (paired discrete footprint impressions, 40 instances) and Diplopodichnus (paired grooves, 106 instances) (Fig. 3). Both forms have a mean width of $6 \mathrm{~mm}$ (Fig. 3J)) and, in 12 instances, Diplichnites transitions to Diplopodichnus along its length (Fig. 3H), indicating the different ichnogenera had a shared tracemaker (as noted by Johnson et al., 1994). A significant difference is that Diplichnites are shorter (average $56 \mathrm{~mm}$ ) and straighter (average sinuosity 1.02) than Diplopodichnus and transitional trackways (average 153 and $197 \mathrm{~mm}$ ) which commonly occur in single or multiple, broadly or tightly arcuate and self-crossing loops (Fig. 3A, D, I). The most likely tracemaker remains a myriapod, as discussed by Johnson et al. (1994), who noted one instance of lateral probing on a trackway (evidenced by a short terminal 'branch' to the main trackway as it curved), implying a laterally-flexible tracemaker. In this study, a further instance of probing (Fig. 3F) in Diplichnites reveals 10 footfall impressions along one side of the length of the probing branch, indicating an organism with at least 20 legs, and confidently eliminating trilobites, chelicerates, crustaceans and hexapods as potential tracemakers.

Johnson et al. (1994) argued that the different forms resulted from the same tracemaker organism walking on wet (Diplopodichnus) or dry (Diplichnites) sediment, but this is unlikely as both forms occur on multiple substrates (i.e., firm, semi-firm, unconsolidated). Additionally, the presence of transitional forms on continuous surfaces which lack topography (e.g., depressions where water may have been 
retained) implies that a single tracemaker could create both ichnogenera during one traverse of a planar, materially-uniform substrate (Fig. $3 \mathrm{H})$. Without a sedimentological cause, the preservation of both trackways must be due to behavioral variation from the tracemaker. Extant myriapods transition from making Diplichnites- to Diplopodichnus-like trackways as their walking speed decelerates (Wilson, 2006), and the occasional widening of Diplopodichnus trails indicates that the organism was also irregularly wobbling the axis of its body, as it moved in self-crossing concentric pathways. Such pathways of motion and trackways have been observed being made by a variety of dying arthropods, including myriapods (Gerdes et al., 1993; Martins-Neto and Gallego, 2006; Hegna, 2012; Martin, 2013; see Appendix). In the rock record, 'mortichnia' can only be conclusively identified by the rare fossilization of the tracemaker, but usually with no evidence for the cause of death. While no body fossils accompany the Lum Pot trackways, a mortichnial origin for the traces is supported by (1) morphometric similarity with unequivocal arthropod mortichnia (e.g., Barthel et al., 1990; Collette et al., 2010; Figure 3K, Appendix); and (2) direct sedimentary evidence for a known cause of arthropod death. Volcanic ash abrades and adheres to arthropod cuticles (causing desiccation and interfering with osmoregulation), enters articular membranes (increasing friction and restricting mobility), and acts as a highly inimical substrate on which to search for resources as its ingestion destroys arthropod digestive and breathing apparatus (Edwards, 2005; Miserendino et al., 2012; Elizalde, 2014). Further, subaqueously remobilized ash can increase arthropod mortality for years after an eruption (Miserendino et al., 2012). As the Lum Pot trackways occur within a sedimentary succession composed almost uniformly of $<0.01 \mathrm{~mm}$ ash, with evidence for post-settling remobilization of ash in the water column (i.e., wave ripples; reentrainment of ash during the erosion of fluted surfaces), the potential for ash-induced mortality would have been severe.

The low ichnodiversity and ichnodisparity of the BVG trackways means that they share few similarities with the diverse trackways and infaunal traces known from Silurian-Devonian non-marine strata, and which record the major global onset of arthropod-sediment interactions on land (Minter et al., 2016; Shillito and Davies, 2017). Statistical comparison reveals stronger similarities with other CambrianOrdovician subaerial trace fossil sites (Fig. 3L), where low diversity arthropod trackways are seen in subaqueously deposited strata with evidence for intermittent emergence (e.g., adhesion marks, desiccation cracks) or fully subaerial strata deposited within a few meters of the paleoshoreline (MacNaughton et al., 2002; Collette et al., 2010; Hagadorn et al., 2011).

\section{CONCLUSIONS}

Rather than providing a trace-fossil record of incipient fully non-marine animal communities, the BVG trackways likely provide one of few globally-distributed snapshots of littoral arthropod activity during the protracted Cambrian-Ordovician prelude to terrestrialization. However, their association with thick ash deposits, and apparent record of distressed behavior, renders them an exceptional fossilized record of organisms interacting with, and dying within, a marginal subaqueous volcanic environment in deep time, in part analogous to modern arthropod response to eruptions.

\section{APPENDIX}

Details of the local stratigraphy, further images of surfaces A-E, = thin sections, comparative images of arthropod mortichnia and details and data for the plots in Figure 3 are provided as an Appendix.

\section{ACKNOWLEDGMENTS}


APS is supported by the Natural Environment Research Council [grant number NE/L002507/1]. We thank M. Branney and S. Gibson for discussions regarding the volcanic setting and L. Buatois, R. Garwood and two anonymous reviewers for helpful comments.

\section{REFERENCES CITED}

Barnes, R.P., Branney, M.J., Stone, P. and Woodcock, N.H., 2006, The Lakesman Terrane: the Lower Palaeozoic record of the deep marine Lakesman Basin, a volcanic arc and foreland basin. In The geology of England and Wales. Geological Society of London, pp. 103-130

Barthel, K.W., Swinburne, N.H.M., and Conway Morris, S., 1990, Solnhofen: A study in Mesozoic palaeontology. Cambridge, Cambridge University Press, $236 \mathrm{p}$.

Branney, M.J., 1988, The subaerial setting of the Ordovician Borrowdale Volcanic Group, English Lake District: Journal of the Geological Society, v. 145, p. 887-890, https://doi.org/10.1144/gsjgs.145.6.0887.

Branney, M.J., 1991, Eruption and depositional facies of the Whorneyside Tuff Formation, English Lake District: An exceptionally large-magnitude phreatoplinian eruption: Geological Society of America Bulletin, v. 103, p. 886-897, https://doi.org/10.1130/0016-7606(1991)103<0886:EADFOT>2.3.CO;2.

Branney, M.J., and Kokelaar, B.P., 2002, Pyroclastic density currents and the sedimentation of ignimbrites: Bath, UK, Geological Society of London Memoir No. 27, 130 p.

Collette, J.H., Hagadorn, J.W., and Lacelle, M.A., 2010, Dead in their tracks-Cambrian arthropods and their traces from intertidal sandstones of Quebec and Wisconsin: Palaios, v. 25, p. 475-486, https://doi.org/10.2110/palo.2009.p09-134r.

Davies, N.S., Rygel, M.C., and Gibling, M.R., 2010, Marine influence in the Upper Ordovician Juniata Formation (Potters Mills, Pennsylvania): Implications for the history of life on land: Palaios, v. 25, p. 527539, https://doi.org/10.2110/palo.2010.p10-025r.

Edwards, J.S., 2005, Animals and volcanoes: survival and revival, in Martí, J., and Ernst, G.G.J., eds., Volcanoes and the environment: Cambridge, Cambridge University Press, p. 250-272, https://doi.org/10.1017/СВ09780511614767.010.

Elizalde, L., 2014, Volcanism and arthropods: a review: Ecología Austral, v. 24, p. 3-16.

Fisher, R.V., and Schmincke, H.U., 1984, Pyroclastic Rocks: Springer-Verlag Berlin Heidelberg, 472 p.

Gerdes, G., Claes, M., Dunajtschik-Piewak, K., Riege, H., Krumbein, W.E., and Reineck, H.E., 1993, Contribution of microbial mats to sedimentary surface structures: Facies, v. 29, p. 61-74, https://doi.org/10.1007/BF02536918.

Hagadorn, J.W., Collette, J.H., and Belt, E.S., 2011, Eolian-aquatic deposits and faunas of the middle Cambrian Potsdam Group: Palaios, v. 26, p. 314-334, https://doi.org/10.2110/palo.2010.p10-061r.

Hegna, T.A., 2012, Phylogeny and fossil record of branchiopod crustaceans: An integrative approach [Ph.D. Thesis]: New Haven, Connecticut, Yale University, 262 p. 
Johnson, E.W., Briggs, D.E.G., Suthren, R.J., Wright, J.L., and Tunnicliff, S.P., 1994, Non-marine arthropod traces from the subaerial Ordovician Borrowdale Volcanic Group, English Lake District: Geological Magazine, v. 131, p. 395-406, https://doi.org/10.1017/S0016756800011146.

Johnson, E.W., Soper, N.J., and Burgess, I.C., 2001, Geology of the country around Ulverston: London, The Stationery Office, $129 \mathrm{p}$.

MacNaughton, R.B., Cole, J.M., Dalrymple, R.W., Braddy, S.J., Briggs, D.E., and Lukie, T.D., 2002, First steps on land: Arthropod trackways in Cambrian-Ordovician eolian sandstone, southeastern Ontario, Canada: Geology, v, 30, p.391-394.

Martin, A.J., 2013, Life traces of the Georgia coast: Revealing the unseen lives of plants and animals: Bloomington, Indiana University Press, $670 \mathrm{p}$.

Martins-Neto, R.G.M., and Gallego, O.F., 2006, "Death behavior"- Thanatoethology, new term and concept: A taphonomic analysis providing possible paleoethologic inferences: Geociencias, v. 25, p. 241254.

Millward, D., 2004, A stratigraphical framework for the upper Ordovician and Lower Devonian volcanic and intrusive rocks in the English Lake District and adjacent areas: British Geological Survey Research Report RR/01/07, $54 \mathrm{p}$.

Minter, N.J., Buatois, L.A., Mángano, M.G., Davies, N.S., Gibling, M.R., and Labandeira, C., 2016, The establishment of continental ecosystems, in Buatois, L.A., and Mángano, M.G., eds., The Trace-Fossil Record of Major Evolutionary Events: Dordrecht, Netherlands, Springer, p. 205-324, https://doi.org/10.1007/978-94-017-9600-2_6.

Miserendino, M.L., Archangelsky, M., Brand, C., and Epele, L.B., 2012, Environmental changes and macroinvertebrate responses in Patagonian streams (Argentina) to ashfall from the Chaitén Volcano (May 2008): The Science of the Total Environment, v. 424, p. 202-212, https://doi.org/10.1016/j.scitotenv.2012.02.054.

Mitchell, G.H., 1956, The Borrowdale Volcanic Series of the Dunnerdale Fells, Lancashire: Geological Journal, v. 1, p. 428-449, https://doi.org/10.1002/gj.3350010504.

Rickards, R.B., and Woodcock, N.H., 2005, Stratigraphical revision of the Windermere Supergroup (Late Ordovician-Silurian) in the southern Howgill Fells, NW England: Proceedings of the Yorkshire Geological Society, v. 55, p. 263-285, https://doi.org/10.1144/pygs.55.4.263.

Shillito, A.P., and Davies, N.S., 2017, Archetypally Siluro-Devonian ichnofauna in the Cowie Formation, Scotland: implications for the myriapod fossil record and Highland Boundary Fault Movement:

Proceedings of the Geologists' Association, v. 128, p. 815-828, https://doi.org/10.1016/j.pgeola.2017.08.002.

Wilson, H.M., 2006, Juliformian millipedes from the Lower Devonian of Euramerica: implications for the timing of millipede cladogenesis in the Paleozoic: Journal of Paleontology, v. 80, p. 638-649, https://doi.org/10.1666/0022-3360(2006)80[638:JMFTLD]2.0.CO;2.

Wilson, P., 2004, Description and implications of valley moraines in upper Eskdale, Lake District: Proceedings of the Geologists' Association, v. 115, p. 55-61. 


\section{FIGURE CAPTIONS}

Figure 1. Geological context of trackway bearing horizons in the BVG at Lum Pot. A) Map showing location of Lum Pot and Sour Milk Gill trackway localities. Inset shows current British Geological Survey (BGS) map for studied locality (see Appendix for discussion of Whorneyside/Dunnerdale boundary); B) Cross-section through the Duddon Basin, along line A-A' (Fig. 1A) showing regional stratigraphic relationships, after Millward (2004). Formations not mentioned in text referred to by BGS lexicon codes (see Millward, 2004); C) Measured stratigraphic log at Lum Pot showing trace-fossil surfaces (log location shown in $1 \mathrm{~A}$; base of log at $54^{\circ} 18$ ? $12.08^{\prime \prime} \mathrm{N}, 3^{\circ} 12$ ? $18.63^{\prime \prime} \mathrm{W}$, top of log at $54^{\circ} 18$ ? $15.21^{\prime \prime} \mathrm{N}, 3^{\circ}$ 12의 13.36"; bedding dips $20^{\circ}$ toward the ESE).

Figure 2. Sedimentological characteristics of the trackway-bearing tuffs at Lum Pot [position on Figure $1 \mathrm{C} \log$ or trackway surface in square brackets]. A) Furrowed grooves developed as overlying ash eroded down to a new semi-firm substrate, later traversed by Diplichnites and Diplopodichnus [Surface D]; B) Unconsolidated substrate revealed by reworking of tuff into bifurcating wave ripple marks. Surface hosts multiple short $(<15 \mathrm{~cm}$ ) trackways (not visible at this scale; locations starred) [Surface B]; C) Homogenous tuff with two vesicular horizons [20.7 m]; D) Pumice clasts (pink arrow) with similar-sized weathered out holes (yellow arrow), plan-view of exposed internal part of tuff bed [22.4 m]; E) Coarse layer of settled ash [ $1 \mathrm{~cm}$ below Surface C2]; F) Aggradational climbing wave ripples in cross section, indicating continuous ash deposition in agitated water [14.0 m]; G) Consolidated substrates revealed by vertical section through small brittle faults and fractures. Overlying $30 \mathrm{~cm}$ tuff bed has a horizontal upper bounding surface $[21.1 \mathrm{~m}] ; \mathrm{H}$ ) Bedding sags arising from impacting ejecta onto a wet substrate. Arrow points to Diplichnites (not visible at this scale) which descends over lip of crater and into sag [Surface C2]; I) Soft-sediment deformation arising from liquefaction of saturated, unconsolidated ash [13.6 m]; J) Banded tuff (B) passing vertically into large ball-and-pillow structures (BP) indicating instance of wholly unconsolidated and liquefied sediment [21.8 m]. Scale bars: $10 \mathrm{~cm}$ (black); $1 \mathrm{~cm}$ (red). See Appendix for larger photographs.

Figure 3. Distribution and form of trackways. A) Scaled sketch showing distribution of Diplopodichnus (pink) and Diplichnites (blue) on Surfaces $\mathrm{C} 1$ and D; B-C) Diplichnites restricted to ripple crests on Surface $B$, sketch shows measured transect of surface topography and distribution of trackways in pink; D-E) Diplopodichnus following microtopography of furrowed Surface D, with sketch as in Figure 3C; F) Evidence for probing behavior at a curve in a Diplichnites trackway [Surface D]; G) Planview of a microfault scarp (top and bottom highlighted in blue) showing Diplichnites passing over scarp lip from left, and rejoining lower foot of scarp at a distance as tracemaker stepped downwards [Surface D]; H) Transition from Diplichnites to Diplopodichnus along same trackway [Surface D]; I) Mean values for sinuosity (see Appendix) and length in the different trackway morphologies: Diplopodichnus, made by slower moving and wobbling tracemakers, are more likely to be seen looping; J) Mean values for width and length in different trackway morphologies: low standard deviation (2.04) of widths supports contention that they were made by the same type of animal; K) Histogram showing the distribution of loop diameter/trace width for all looped examples, and similar clustering of known mortichnia. Values 
from known arthropod mortichnia (see Appendix) are marked as a - Silurian myriapod, b - Cambrian euthycarcinid, $c$ - modern dipteran, $d$ - modern apterygote, e - Jurassic xiphosuran; L) Multivariate cluster analysis showing similarity of trace fossil communities in coastal and alluvial settings from the Cambro-Ordovician (C-O), Silurian (S) and Devonian (D) (see Appendix). See Appendix for larger photographs. 


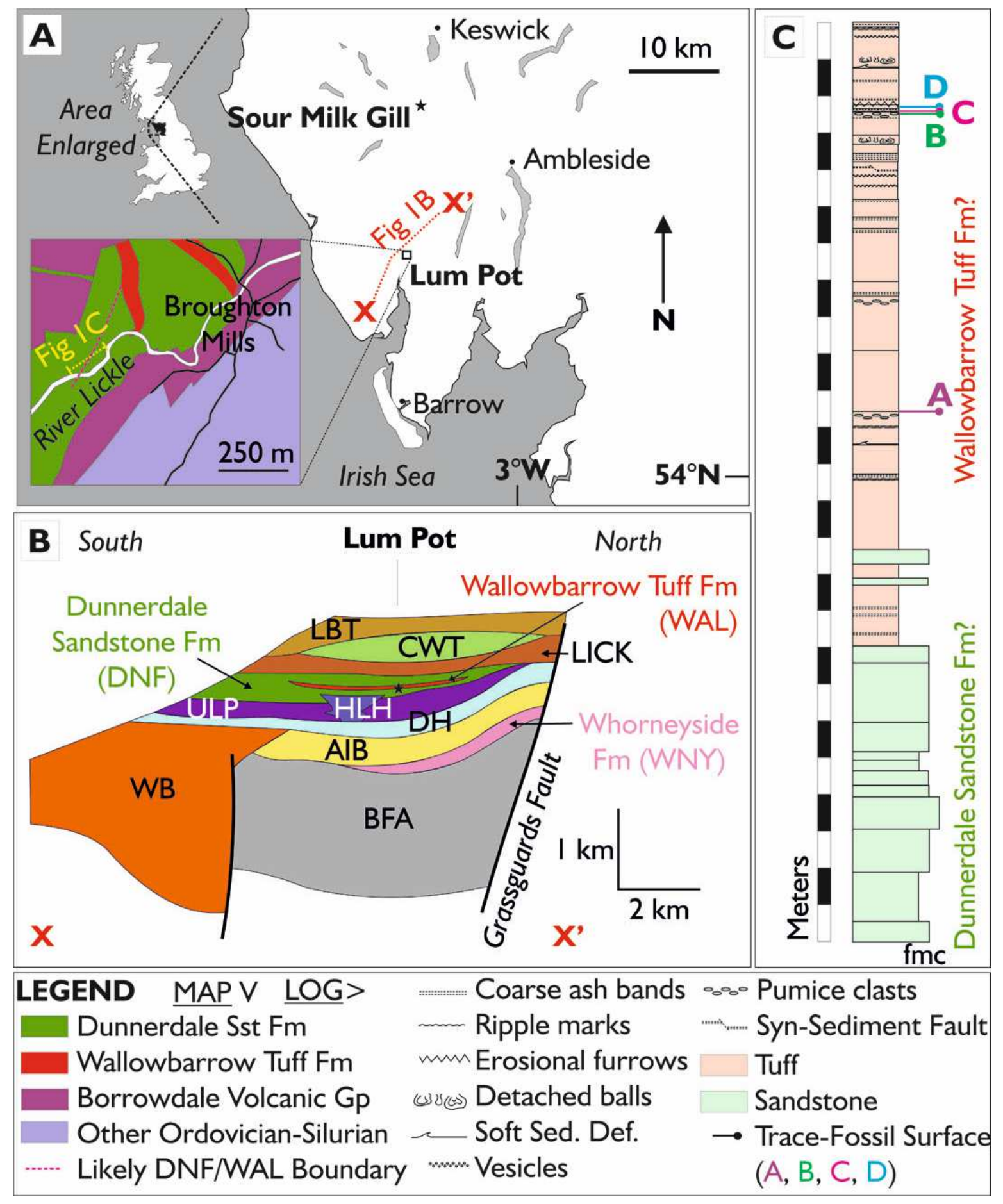

FIGURE 1 


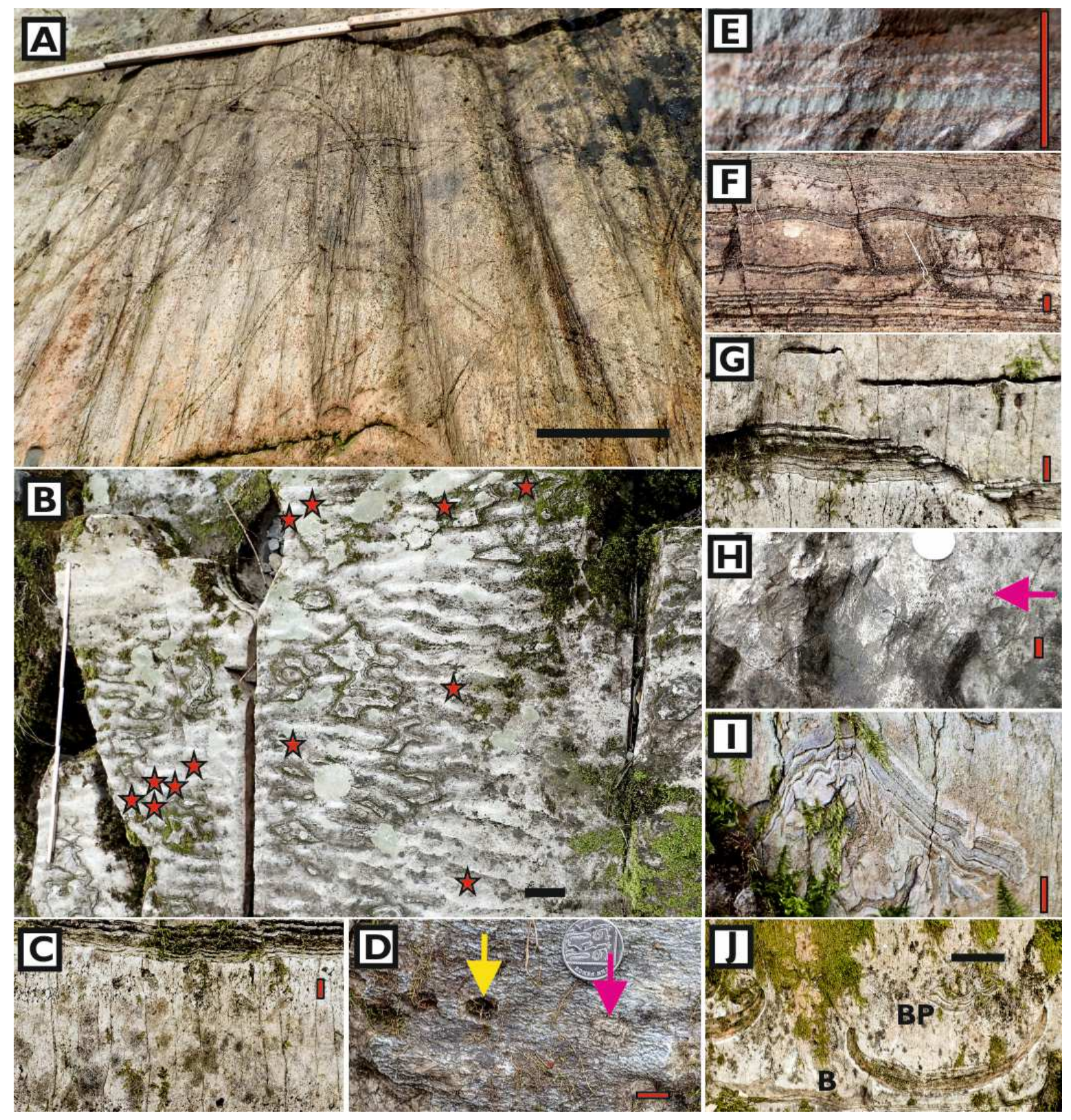

FIGURE 2 

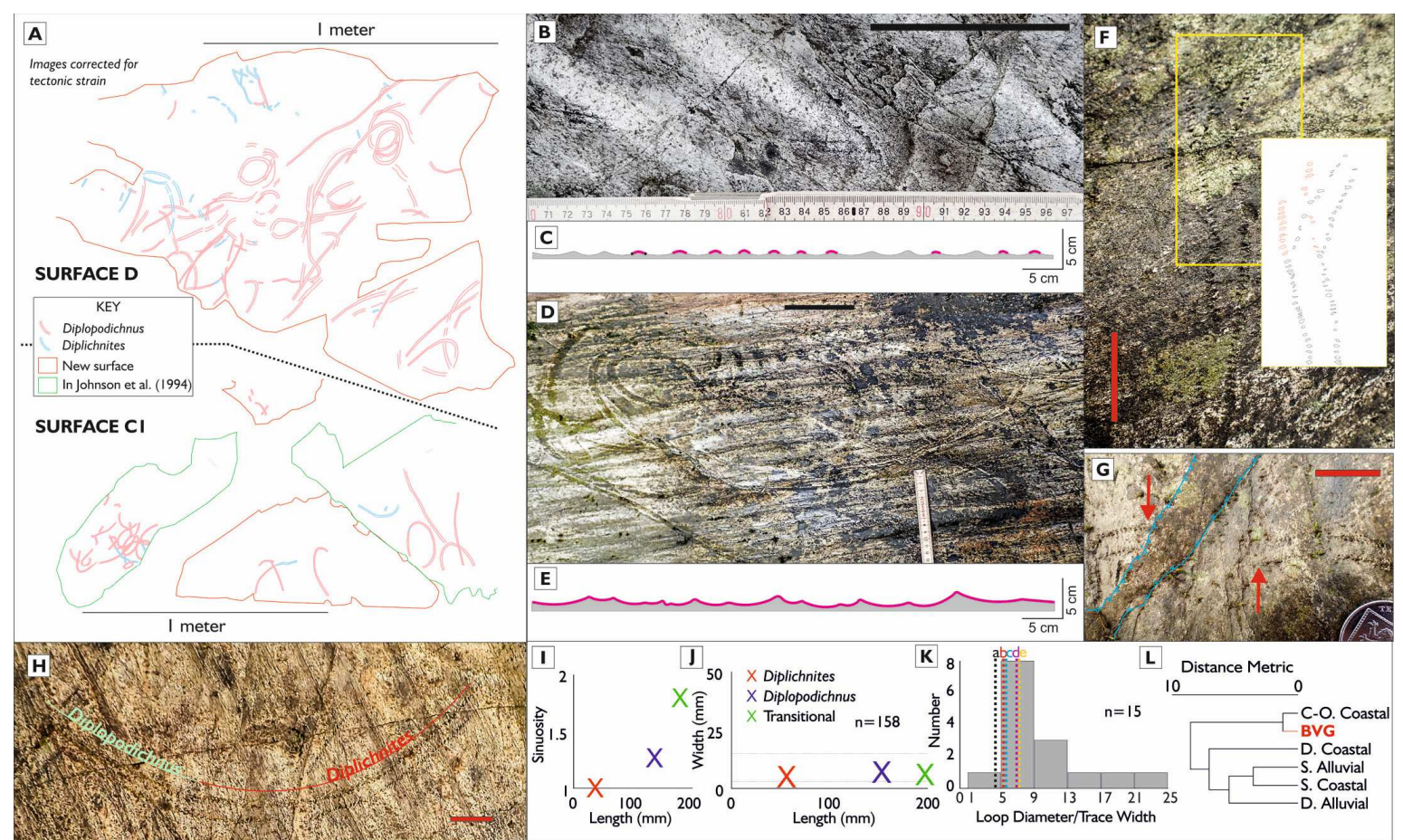

FIGURE 3 


\section{Supplementary Material: Death near the Shoreline, not Life on}

\section{Land: Ordovician Arthropod Trackways in the Borrowdale}

\section{Volcanic Group, UK Anthony P. Shillito and Neil S. Davies}

\section{STRATIGRAPHIC CONTEXT OF THE TRACKWAYS}

The Lum Pot site, where the arthropod trackways occur, was described as being in the Dunnerdale Sandstone Formation (DNF) by Johnson et al. (1994), and is presently mapped as such by the British Geological Survey (BGS). In this paper we consider it more likely that the trackways are within the Wallowbarrow Tuff Formation (WAL), which is a localized stratigraphic unit bounded above and below by the DNF (Figure 1B). This conclusion is based on the fact that the lithology of the Lum Pot stream section consists of at least 14 meters of continuous tuff, whereas, by definition, the DNF consists entirely of volcanoclastic sandstones and breccia (Millward, 2004). The sandstone lithology of the trackway beds, as previously reported, was inconsistent and incorrect (described by Johnson et al. (1994) variably as fine-grained sandstone (p. 397, 404), fineto medium-grained sandstone (p. 397) or medium- to coarse-grained sandstone (p. 398, 399)). Additionally, the presence of WAL at the locality is not surprising: whilst existing BGS bedrock maps show the predicted DNF/WAL boundary to be approximately 200 meters upstream on the River Lickle from Lum Pot, such a boundary is not exposed in the field. The drift cover, extensive faulting, and lack of continuous exposure in the area means that existing maps are, at least in part, conjectural but the re-identification of the Lum Pot rocks as tuff (as originally noted by Mitchell, 1956) identifies the WAL as the most likely host stratigraphic unit (Figure S1).
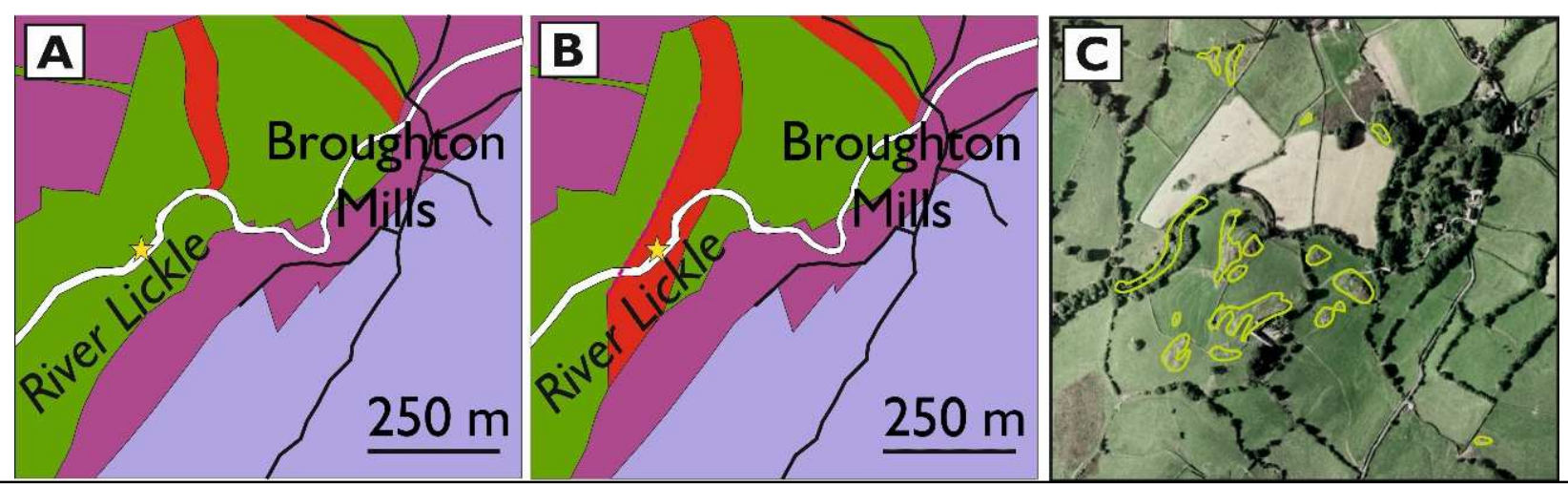

Figure S1. Geological maps of the Lum Pot site, with trace-fossil site starred. WAL shown in red and DNF in green: see Figure 1 for full key. A) Current BGS map; B) Proposed map, based on tuff outcrop along the River Lickle; C) Limited outcrop exposure (highlighted in green) on which map in A was based. (C) 2018 Google Earth, Infoterra \& Bluesky. 


\section{TRACKWAY SURFACES}

Johnson et al. (1994) recorded two trackway-bearing surfaces at Lum Pot: a bed with abundant trails on top (here, Surface C1), and a bed with sparse trails on a rippled surface (here, Surface B). In this study we identified three further surfaces bearing trackways, referring to them in stratigraphic order from oldest to youngest $(\mathrm{A}, \mathrm{B}, \mathrm{C} 1, \mathrm{C} 2$, and $\mathrm{D}$, where $\mathrm{C} 2$ is a different surface of the same bed as C1, exposed on the south side of the River Lickle). A description of each of the trackway bearing surfaces, and their position in the local stratigraphy, is shown in Table S1. The outcrop of each surface is shown in Figures S2-S6, with trackways traced onto the photographs in pink (Diplopodichnus) and blue (Diplichnites).

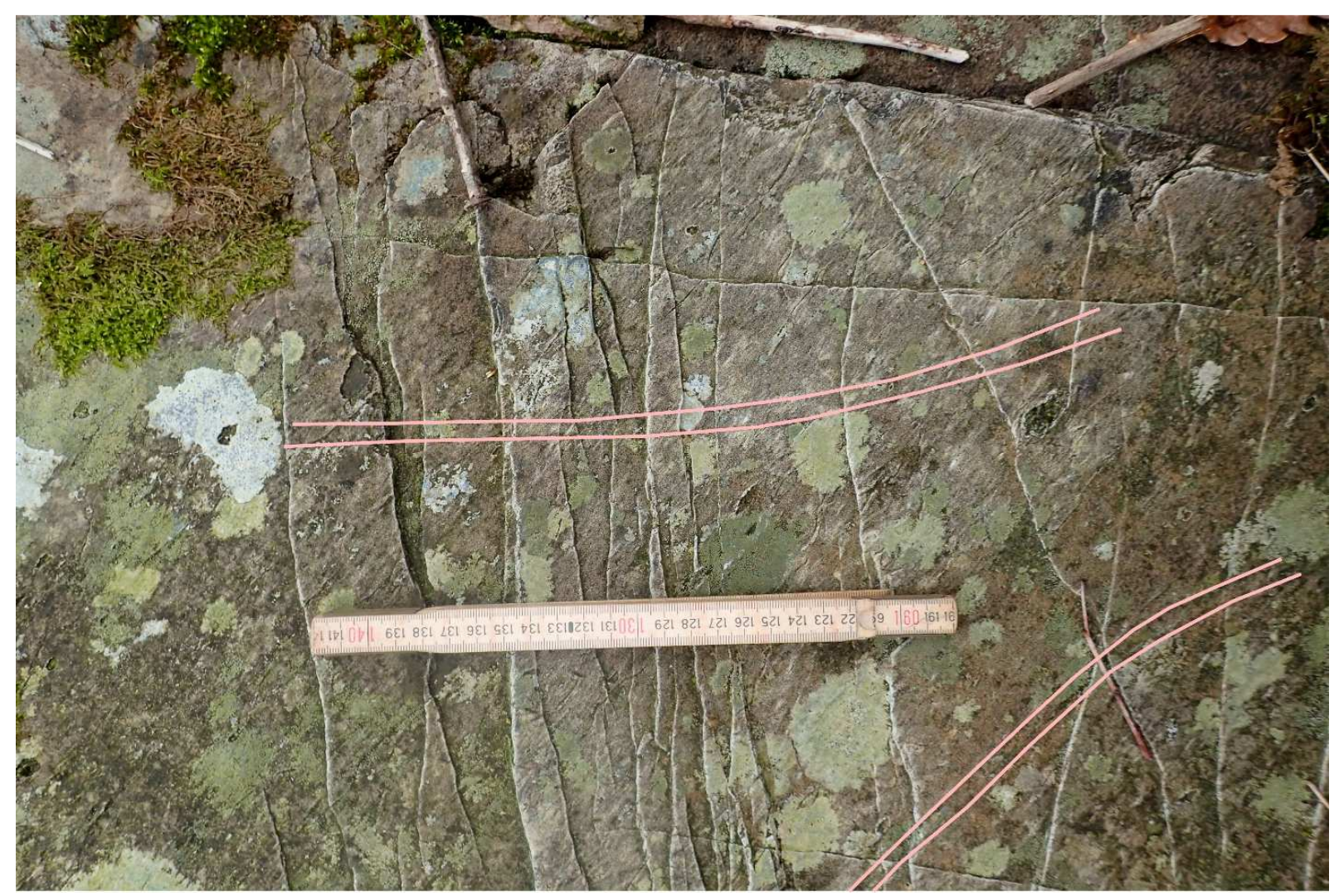

Figure S2. Surface A (ruler is $24 \mathrm{~cm}$ ). 


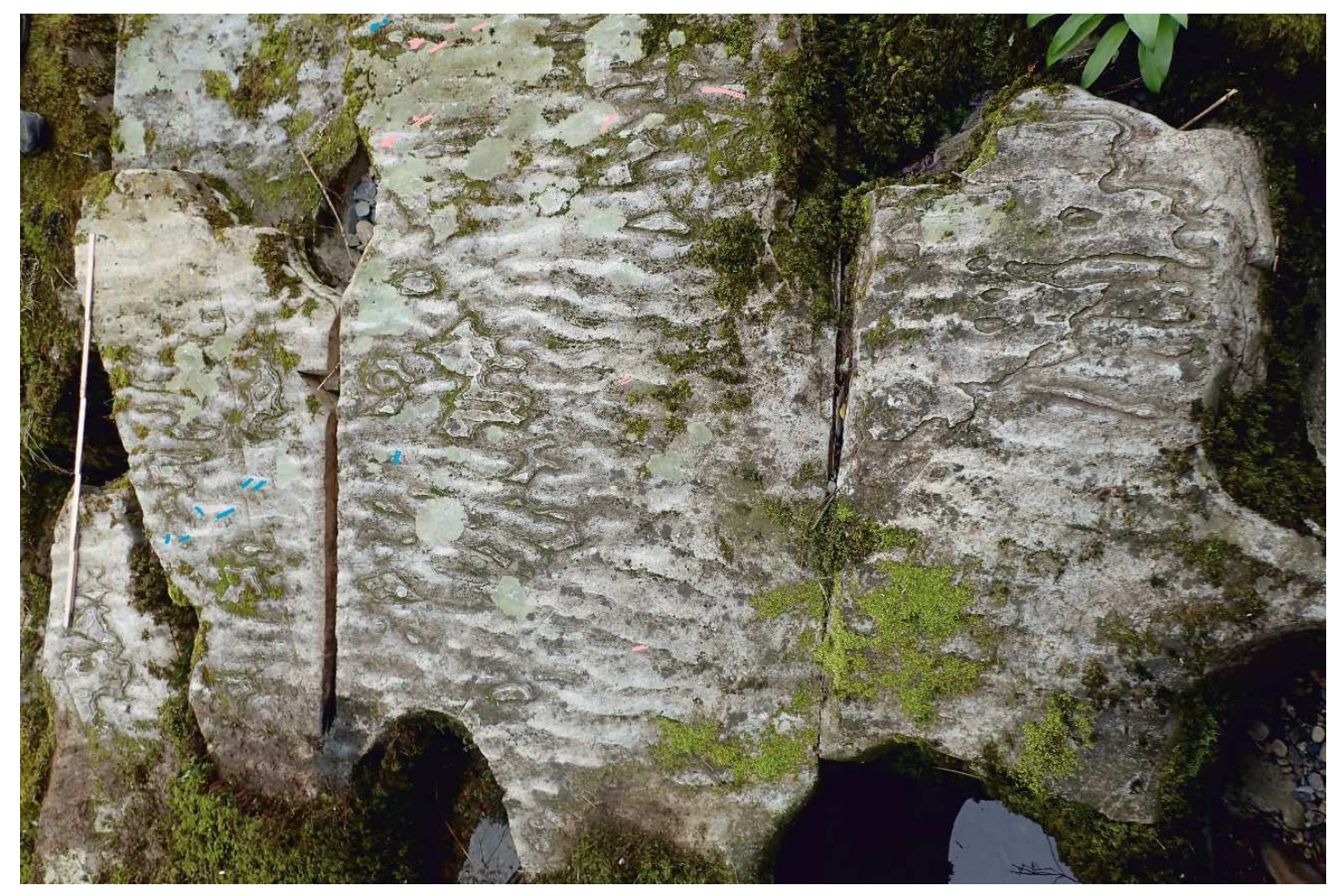

Figure S3. Surface B (ruler is 1 meter).

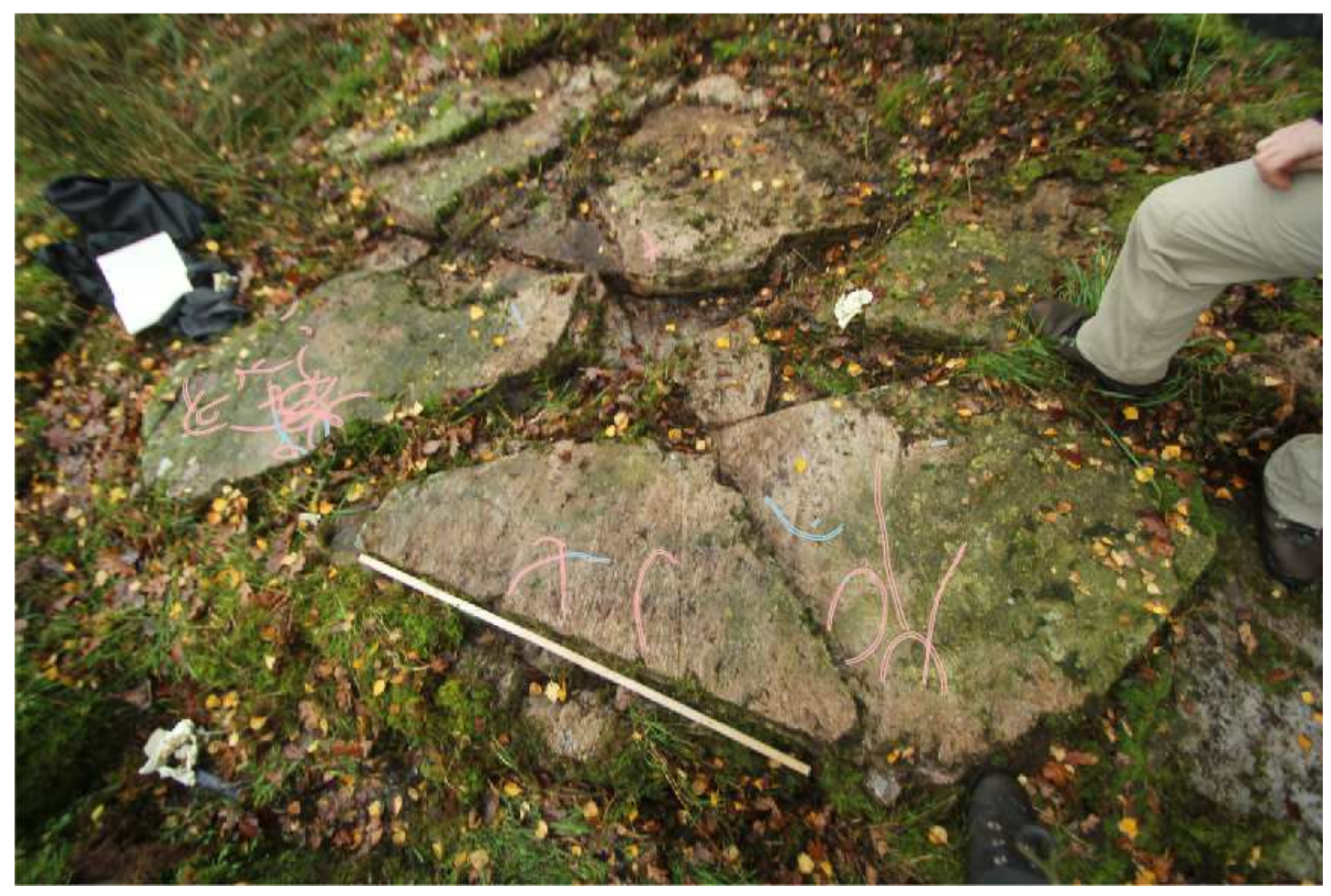

Figure S4. Surface C1 (ruler is 1 meter). 


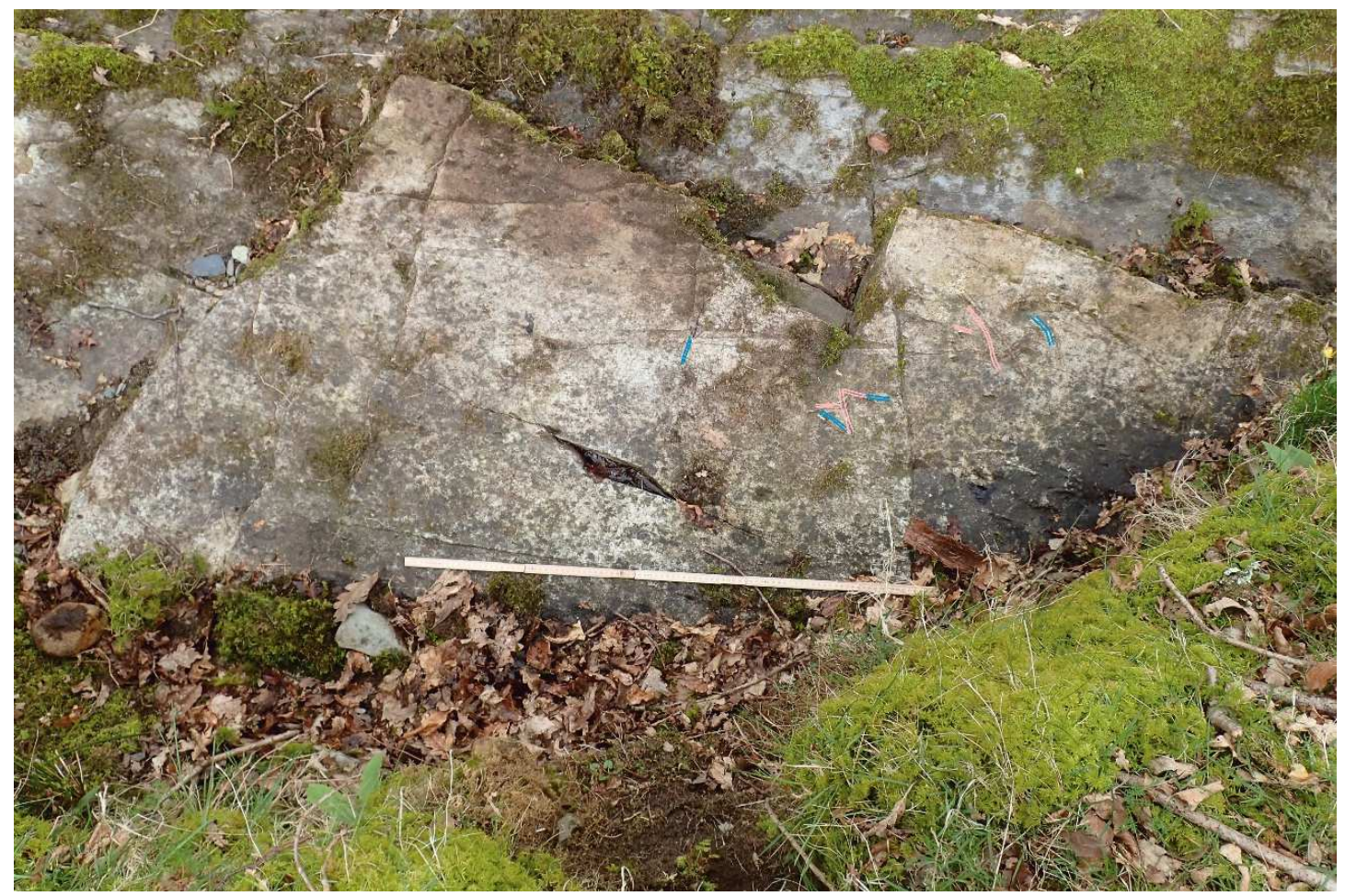

Figure S5. Surface C2 (ruler is 1 meter).

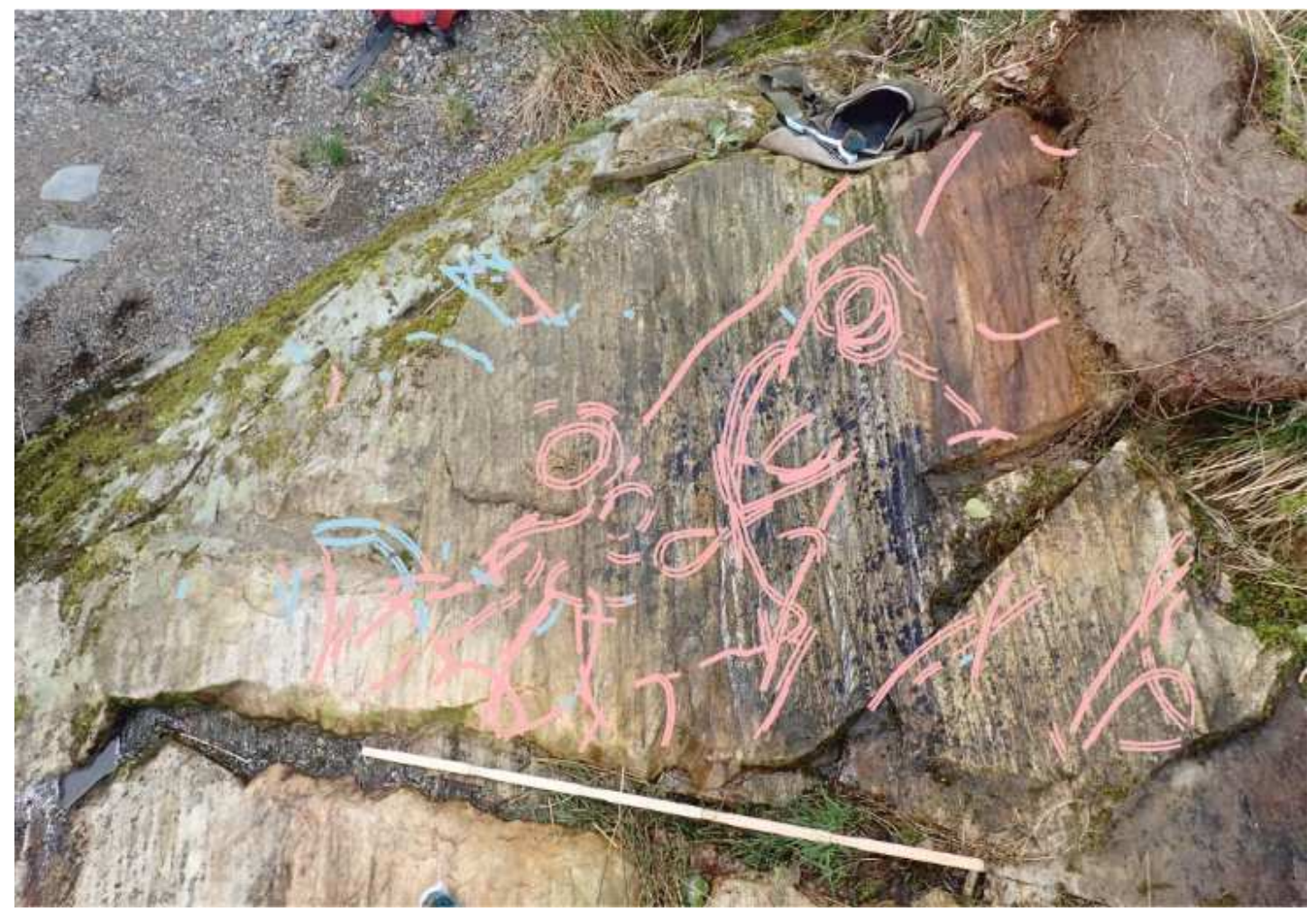

Figure S6. Surface D (ruler is 1 meter). 


\begin{tabular}{|c|c|c|c|c|c|c|c|c|c|c|c|}
\hline & & & & & & \multicolumn{3}{|c|}{ Number of Traces } \\
\hline Surface & Location & $\begin{array}{l}\text { Local Strat (Fig } \\
\text { 1C) }\end{array}$ & $\begin{array}{l}\text { Regional } \\
\text { Strat. }\end{array}$ & Latitude & Longitude & Lithology & $\begin{array}{c}\text { Surface } \\
\text { area }\end{array}$ & Primary Surface Features & Diplichnites & Diplopod. & Transitional \\
\hline A & $\begin{array}{l}\text { Lum Pot, North Side of River } \\
\text { Lickle }\end{array}$ & $15.50 \mathrm{~m}$ & Wallowbarrow & $\begin{array}{l}54^{\circ} 18^{\prime} \\
12.16^{\prime \prime} \mathrm{N}\end{array}$ & $\begin{array}{l}3^{\circ} 12^{\prime} 16.65^{\prime \prime} \\
W\end{array}$ & Tuff & $0.14 \mathrm{~m}^{2}$ & Brittle failure scarps? (may be secondary) & 0 & 2 & 0 \\
\hline B & $\begin{array}{l}\text { Lum Pot, North Side of River } \\
\text { Lickle }\end{array}$ & $22.56 \mathrm{~m}$ & Wallowbarrow & $\begin{array}{l}54^{\circ} 18^{\prime} \\
12.79^{\prime \prime} \mathrm{N}\end{array}$ & $\begin{array}{l}3^{\circ} 12^{\prime} 15.39^{\prime \prime} \\
W\end{array}$ & Tuff & $2.86 \mathrm{~m}^{2}$ & Wave Ripples & 8 & 10 & 1 \\
\hline C1 & $\begin{array}{l}\text { Lum Pot, North Side of River } \\
\text { Lickle }\end{array}$ & $22.61 \mathrm{~m}$ & Wallowbarrow & $\begin{array}{l}54^{\circ} 18^{\prime} \\
12.85^{\prime \prime} \mathrm{N}\end{array}$ & $\begin{array}{l}3^{\circ} 12^{\prime} 15.56^{\prime \prime} \\
W\end{array}$ & Tuff & $1.96 \mathrm{~m}^{2}$ & Brittle failure scarps? (may be secondary) & 4 & 24 & 3 \\
\hline C2 & $\begin{array}{l}\text { Lum Pot, South Side of River } \\
\text { Lickle }\end{array}$ & $22.61 \mathrm{~m}$ & Wallowbarrow & $\begin{array}{l}54^{\circ} 18^{\prime} \\
12.41^{\prime \prime} \mathrm{N}\end{array}$ & $\begin{array}{l}3^{\circ} 12^{\prime} 15.16^{\prime \prime} \\
W\end{array}$ & Tuff & $1.11 \mathrm{~m}^{2}$ & $\begin{array}{l}\text { Low amplitude ripples, Pumice, Bedding } \\
\text { sags }\end{array}$ & 3 & 4 & 1 \\
\hline D & $\begin{array}{l}\text { Lum Pot, North Side of River } \\
\text { Lickle }\end{array}$ & $22.92 \mathrm{~m}$ & Wallowbarrow & $\begin{array}{l}54^{\circ} 18^{\prime} \\
13.45^{\prime \prime} \mathrm{N}\end{array}$ & $\begin{array}{l}3^{\circ} 12^{\prime} 14.41^{\prime \prime} \\
W\end{array}$ & Tuff & $1.92 \mathrm{~m}^{2}$ & Erosional furrows, Brittle failure scarps & 25 & 66 & 7 \\
\hline $\mathrm{x}$ & Sour Milk Gill, Seathwaite & Unknown & Unknown & $\begin{array}{l}54^{\circ} 29^{\prime} \\
57.30^{\prime \prime} \mathrm{N}\end{array}$ & $\begin{array}{l}3^{\circ} 11^{\prime} 36.66^{\prime \prime} \\
W\end{array}$ & Sandstone? & $0.01 \mathrm{~m}^{2}$ & None & 3 & 0 & 0 \\
\hline
\end{tabular}

Table S1. Contextual information for trackway surfaces studied in this paper (A-D) and Johnson et al. (1994) (C1, X). 

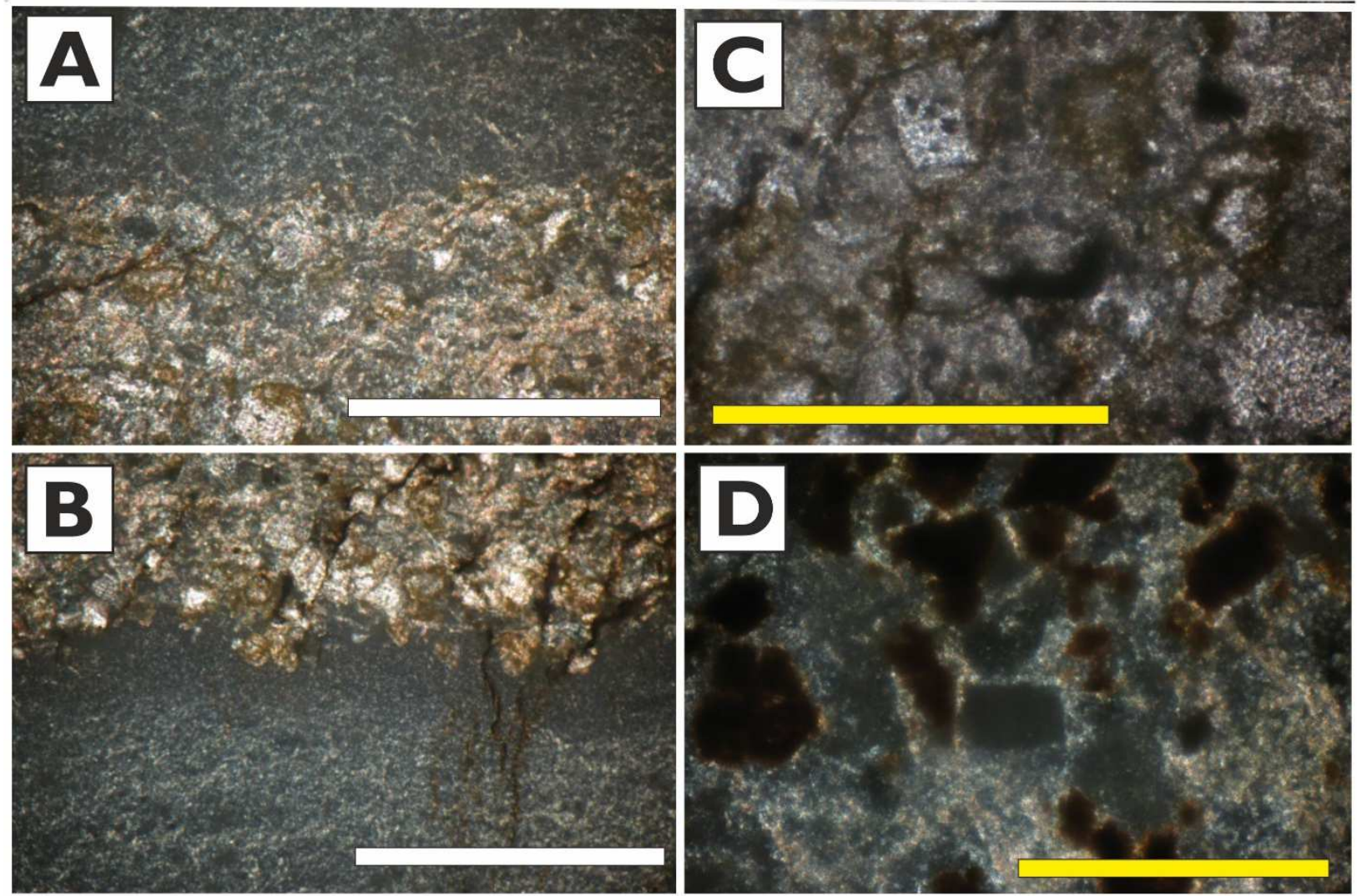

Figure S7. Images of tuff in thin section: A) Bottom of $3 \mathrm{~mm}$-thick coarser ash fall layer (see Figure 2G), showing feldspar-dominated grains settling into cryptocrystalline ash [Surface (2]; B) top of same layer, succeeded by more fine ash [Surface $(2$ ]; C) subhedral alkali feldspar grains [Surface C2]; D) subhedral opaque oxides [8.1 m]. Scale bars $0.5 \mathrm{~mm}$ (white), $0.25 \mathrm{~mm}$ (yellow). 


\section{SUBSTRATE FIRMNESS}

The Lum Pot succession contains evidence that the substrates traversed by the tracemakers had varying degrees of consolidation, irrespective of how wet they were (Table S2). The different material properties of these substrates placed a control on the potential for trackways to be emplaced. The table below shows the suspected likelihood of trackways on substrates of different firmness in different states of moistness, and instances where these were seen.

\begin{tabular}{|c|c|c|c|c|c|c|}
\hline \multirow{2}{*}{$\begin{array}{c}\text { Substrate } \\
\text { firmness }\end{array}$} & \multirow[b]{2}{*}{$\begin{array}{l}\text { Examples } \\
\text { (Figures) }\end{array}$} & \multirow[b]{2}{*}{ Evidence } & \multicolumn{2}{|c|}{ Potential Trackways } & \multicolumn{2}{|c|}{ Seen Trackways } \\
\hline & & & Wet & Dry & Wet & Dry \\
\hline $\begin{array}{l}\text { Unconsolidated } \\
\text { (granular) }\end{array}$ & $\begin{array}{c}2 \mathrm{~F}, 2 \mathrm{H}, 2 \mathrm{I}, 2 \mathrm{~J} \\
2 \mathrm{~K}, 3 \mathrm{~B}\end{array}$ & $\begin{array}{l}\text { Various soft-sediment } \\
\text { deformation structures, } \\
\text { ripple marks }\end{array}$ & $\mathrm{N}$ & $Y$ & $\mathrm{~N}$ & $Y$ \\
\hline $\begin{array}{l}\text { Semi-firm } \\
\text { (cohesive) }\end{array}$ & $2 A, 3 D, 3 F, 3 H$ & $\begin{array}{l}\text { Furrowed erosion surface } \\
\text { indicating erosion down to a } \\
\text { more cohesive layer within } \\
\text { ash deposit }\end{array}$ & $Y$ & ? & $Y$ & ? \\
\hline Firm (cohesive) & $2 N, 3 G$ & $\begin{array}{c}\text { Brittle syn-sedimentary } \\
\text { deformation, fracture scarps }\end{array}$ & $Y$ & $\mathrm{~N}$ & $Y$ & $\mathrm{~N}$ \\
\hline
\end{tabular}

Table S2. Evidence for unconsolidated, semi-firm and firm ash substrates in the Lum Pot section and their propensity for being imparted with trackways when wet and dry.

\section{TRACKWAY MORPHOLOGY}

The plots shown in Figure 3I-K show the morphometric characteristics of the trackways (measurements in Tables S3-S5 at the end of this appendix). All trace fossil dimensions were corrected to account for a regional tectonic shortening of approximately $30 \%$, with the direction of shortening determined from the cleavage in each trackway-hosting bed (Johnson et al., 1994). Figure 3J (shown in full as Figure S8, and including the three trackways from Sour 
Milk Gill) shows how the width of the trackways is consistent regardless of length or ichnogenera, supporting the notion of a single type of tracemaker.

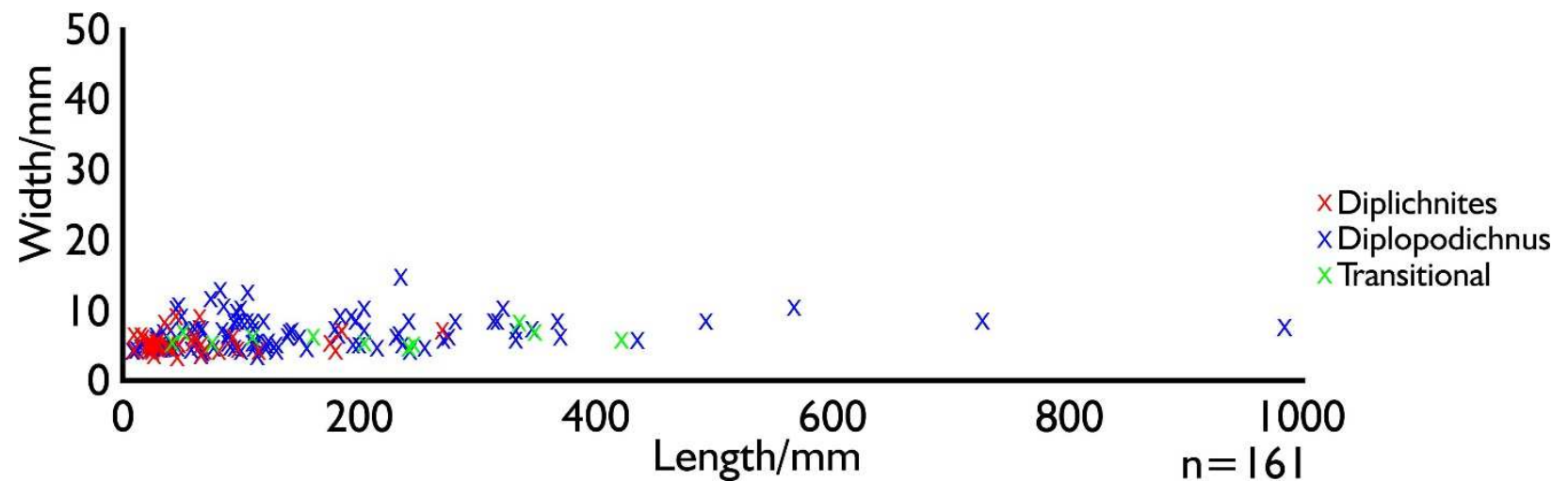

Figure S8. Length-width graph shows that all traces are of similar width, fitting very closely to a normal distribution (standard deviation =2.04). The lengths of the traces have a much greater range and far higher standard deviation (=135.93) highlighting the more variable nature of the values.

The graph showing sinuosity against length (Figure 3I, S9) shows that Diplopodichnus tracks, reflecting slow moving and wobbling tracemakers, were more likely to be long and looping than the Diplichnites tracks. Looping, common in mortichnial trails, was approximated with a measurement of sinuosity: the ratio of the length of a trace to its distance, where "distance" records the minimum distance between the end points of a trace in a straight line, and "length" records the distance between the end points of a trace when following the path of the trace. 


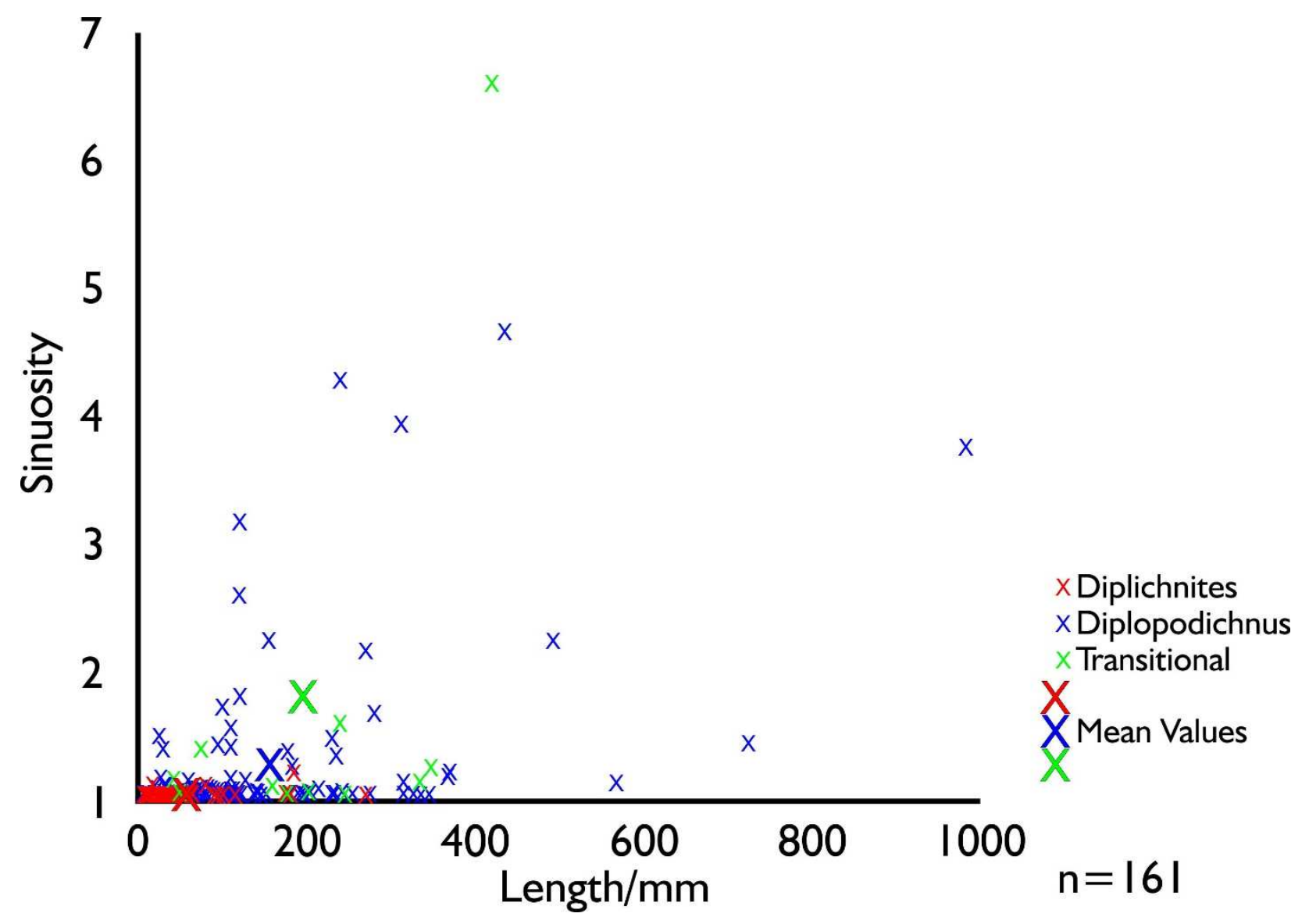

Figure S9. Sinuosity-length graph shows that most of the observed traces have a sinuosity below 1.1, including all but 3 examples of Diplichnites. Diplopodichnus and transitional forms exhibit a much greater range of sinuosities, and higher mean values.

Looping of the trackways was further quantified as a ratio of the diameter of the loop in the region of the tightest curvature to the mean width of the trace along its length (Figure $3 \mathrm{~K}$; Figure S10). The degree of shortening in the Lickle area is reported to be approximately $30 \%$ (Johnson et al., 1994). This was corrected for using photo manipulation to artificially adjust the traces to their original proportions. Diameter was divided by trace width to produce a ratio comparable with other global examples of known or suspected mortichnia independent of the size of the trace maker. This was then presented as a histogram with bin size 4, starting from the minimum possible ratio (1.0). Published examples of arthropod mortichnia that were measured for comparison included the death trail of a Jurassic xiphosauran (in Barthel et al., 1990; their Fig. 5.5; 'e' in Figure 3K) and Cambrian euthycarcinid (in Collette et al., 2010; their Fig. 3D; 'b' in Figure 3K). Unpublished instances are shown in Figures S11-15. 
Myriapod death trails illustrated by Martins-Neto and Gallego (2006) are omitted as no scale was shown with their image (their Fig. 4D).

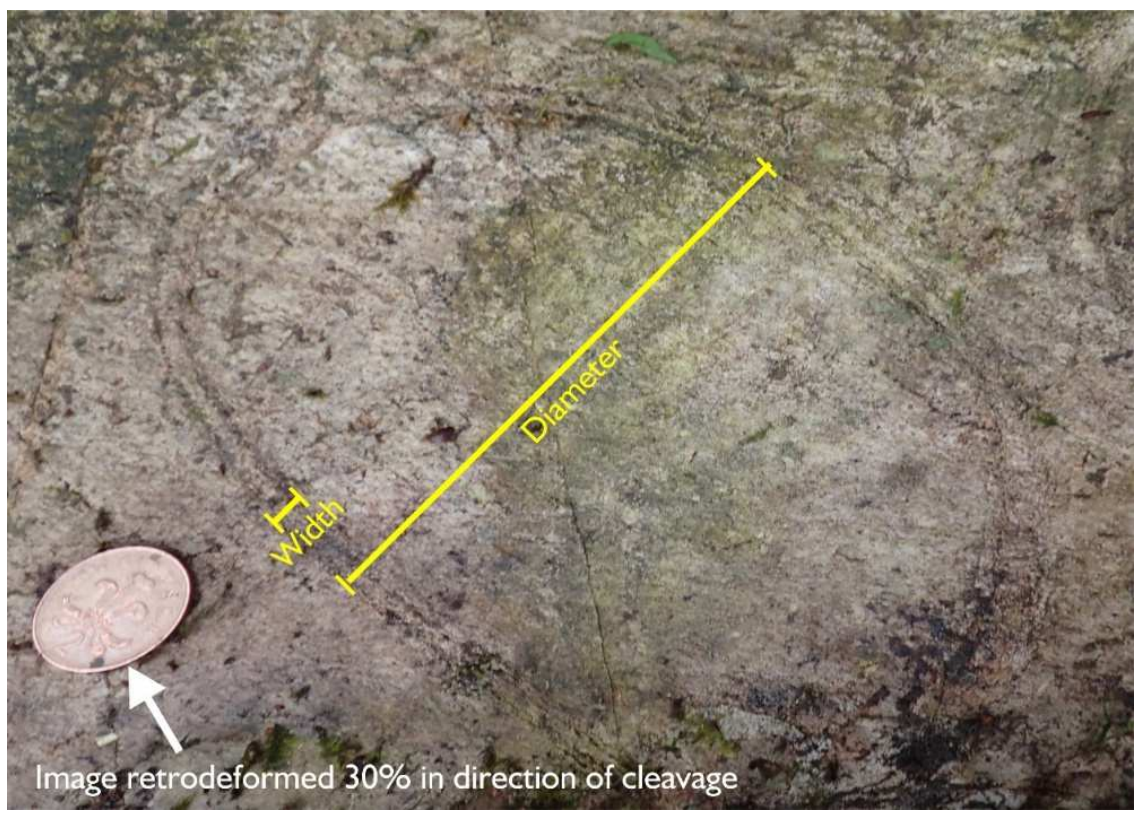

Figure S10. Measurements taken in the construction of Figure $3 \mathrm{~K}$ (example is on Surface C1).

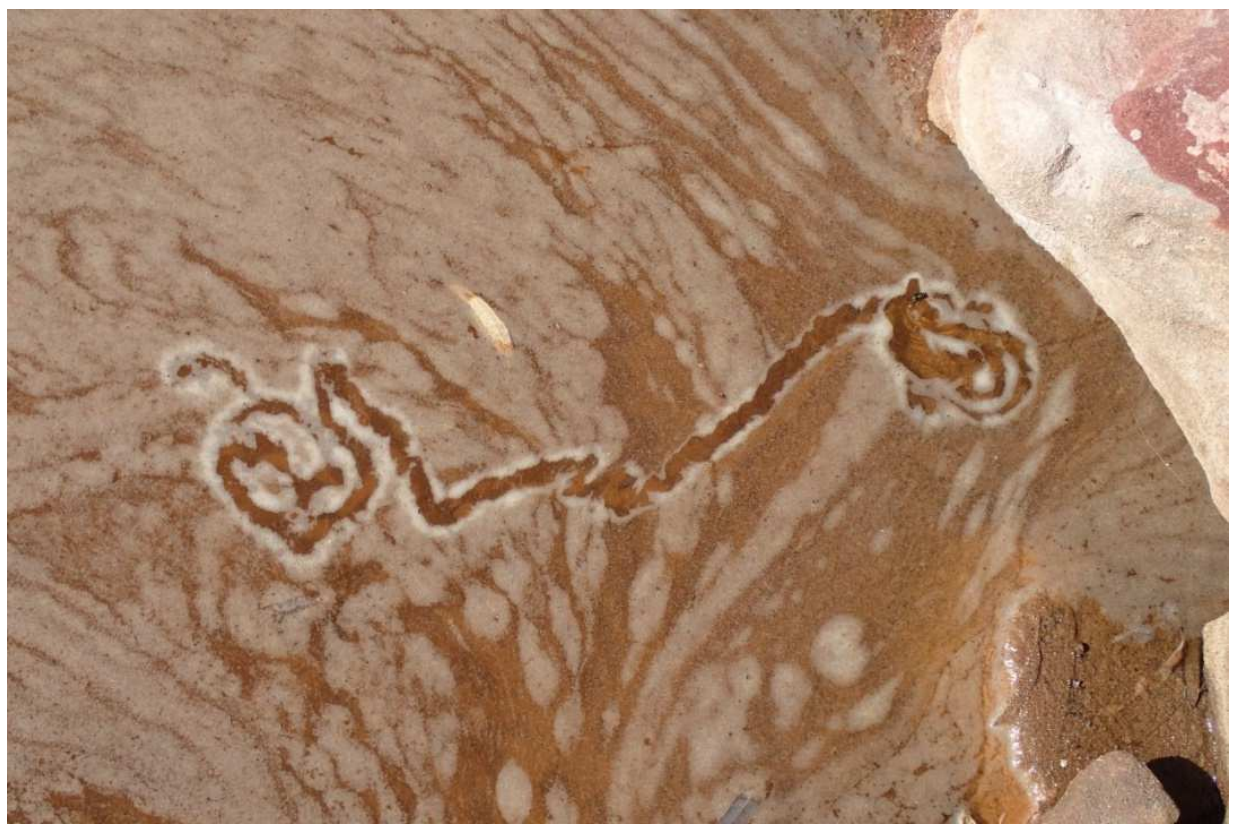

Figure S11. Self-crossing looping trail of a dying dipteran trapped on the surface of a pond.

Murchison River, Western Australia ('c' in Fig. 3K). 


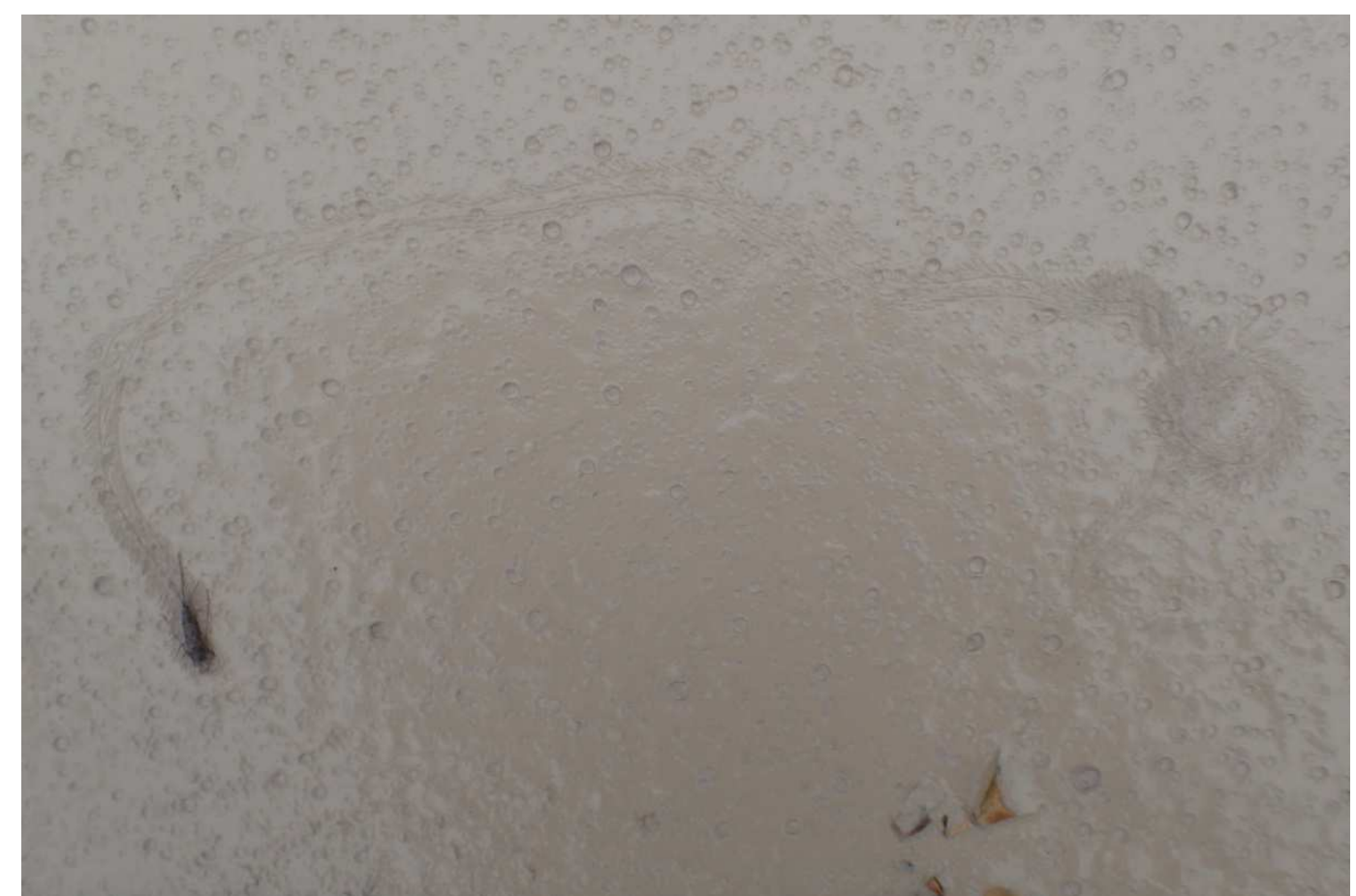

Figure S12. Looping and self-crossing mortichnia of a dead silverfish (Zygentoma) observed on modern mudflat. Hastings, Sussex, UK ('d' in Fig. 3K).

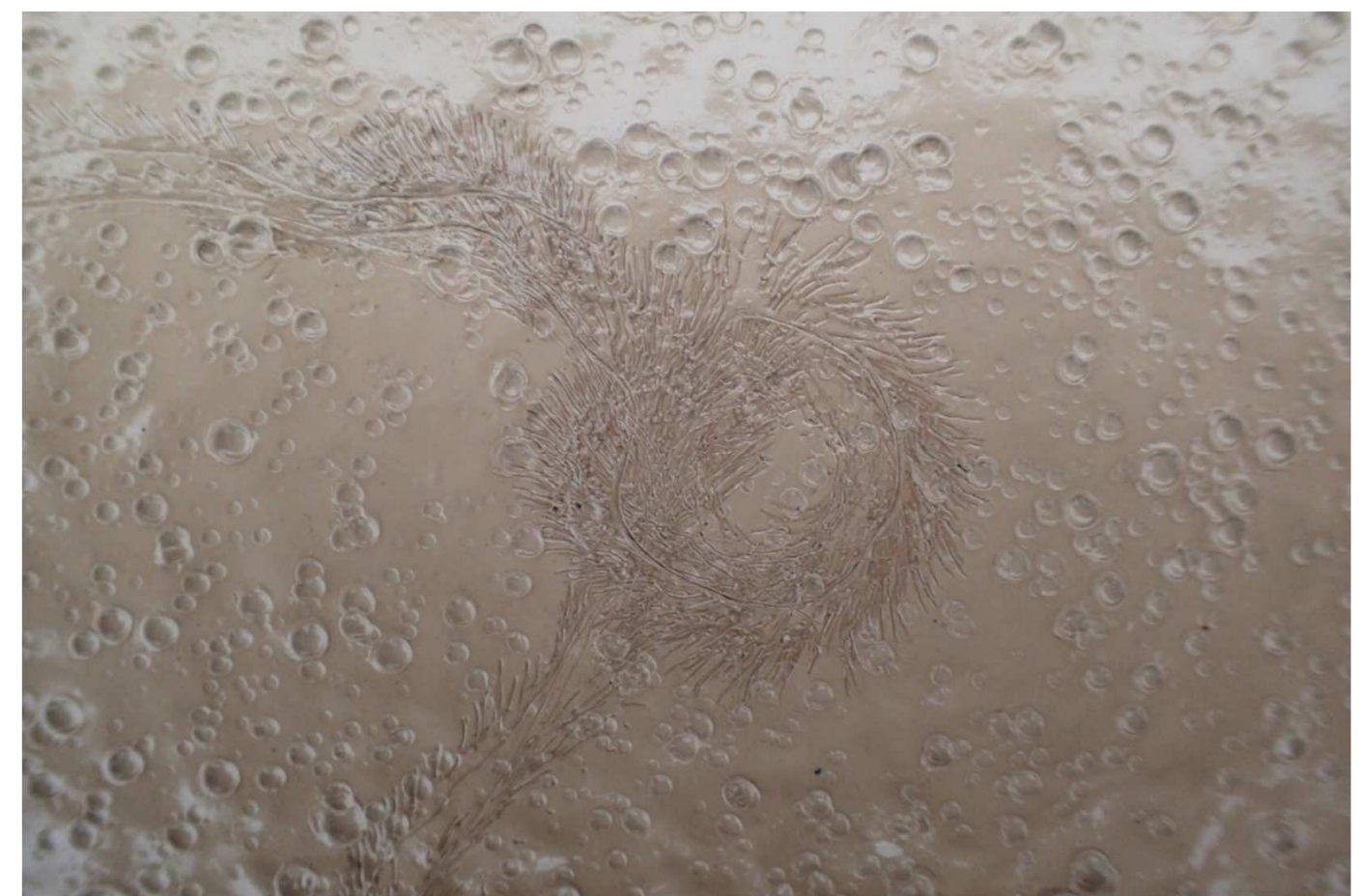

Figure S13. Detail of Figure S12 showing irregular widening of trail as dying silverfish wobbling and walked in circles. 


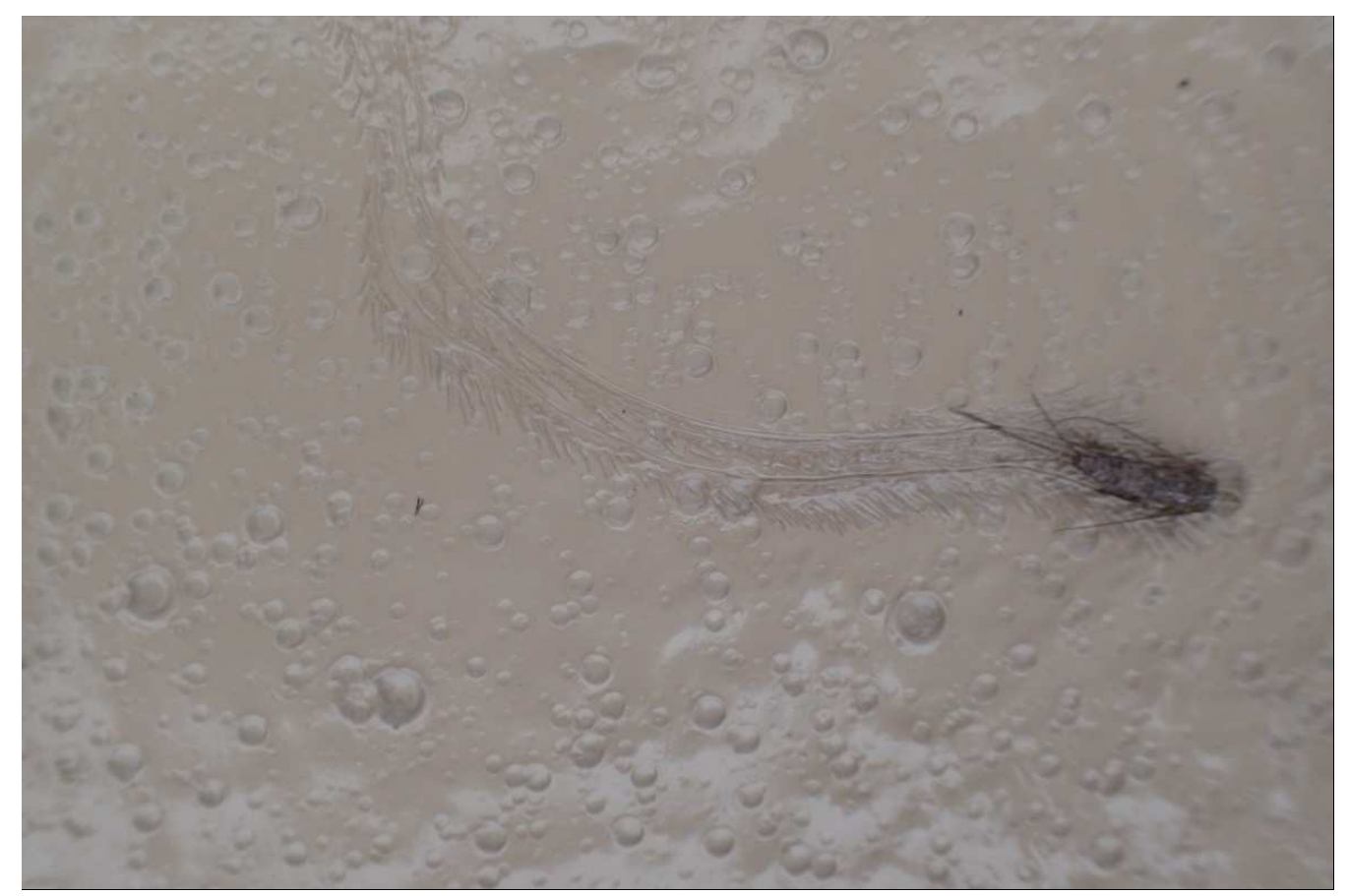

Figure S14. Detail of Figure S12 showing irregular widening of trail as dying silverfish wobbling and walked in circles.

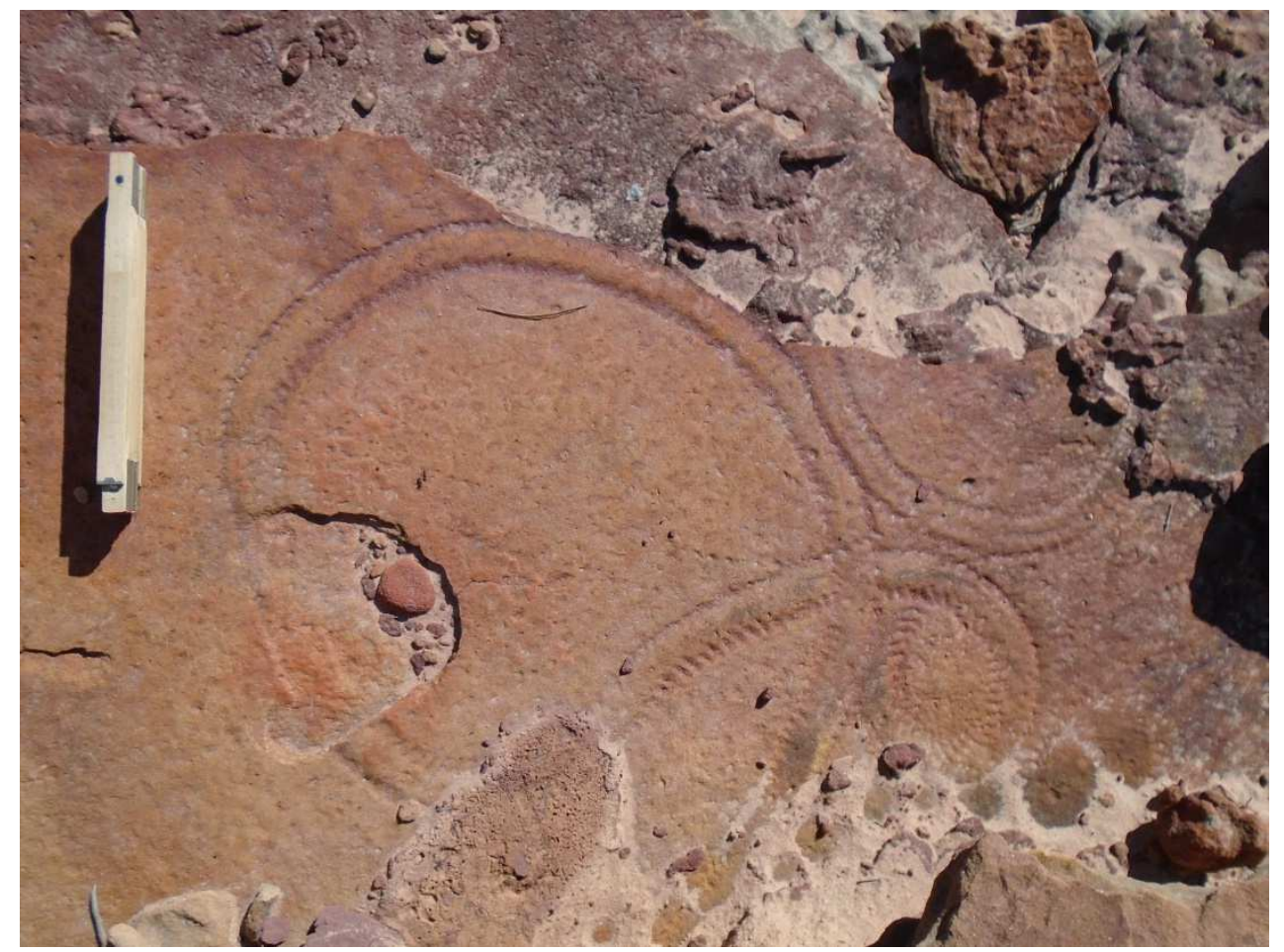

Figure S15. Suspected but unconfirmed mortichnial trail of a myriapod in the Silurian Tumblagooda Sandstone, Western Australia. Facies Asssociation 2 of this formation contains hundreds of examples of Diplichnites but this is the only trail to show looping, suggesting a rarer form of behavior (i.e., suspected to be dying) than other trackways in the formation (' $a$ ' in Fig. 3K).

\section{OTHER COMPARATIVE NEOICHNOLOGY}


Comparative neoichnology also provides analogues for instance where footprints are seen only on ripple crests (i.e., where dry granular sediment on ripple crestlines preserves footprint indents, but saturated granular sediment within troughs cannot retain such impressions). Figures S16-17 show examples of similar arthropod traces within damp fine-grained sands within an intertidal zone (Rainy Cove, Nova Scotia, Canada).

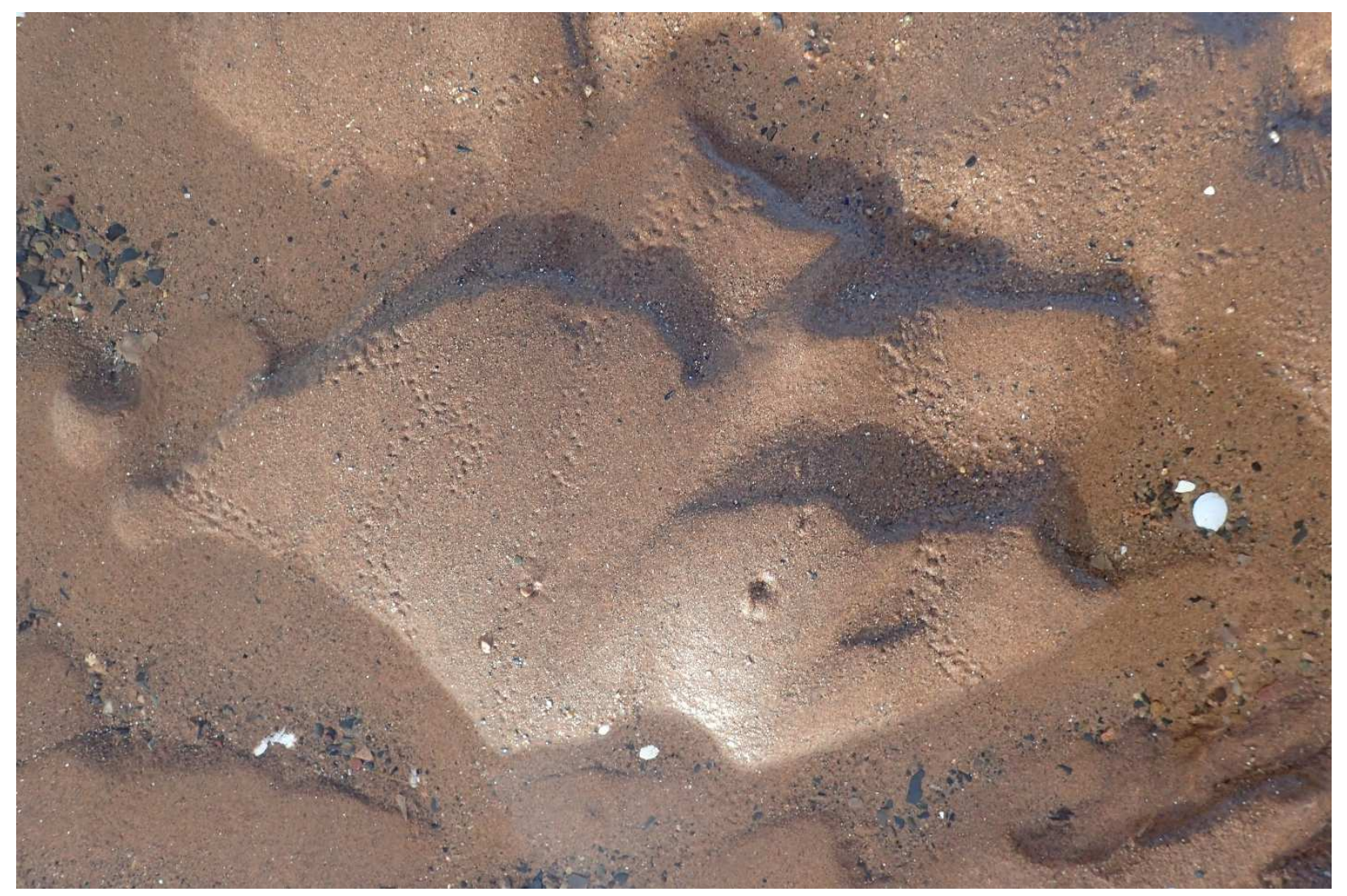

Figure S16. Preservation of footprint indents on damp ripple crests, but absent in waterlogged ripple troughs. Intertidal sands at low tide, Rainy Cove, Bay of Fundy, Nova Scotia, Canada. 


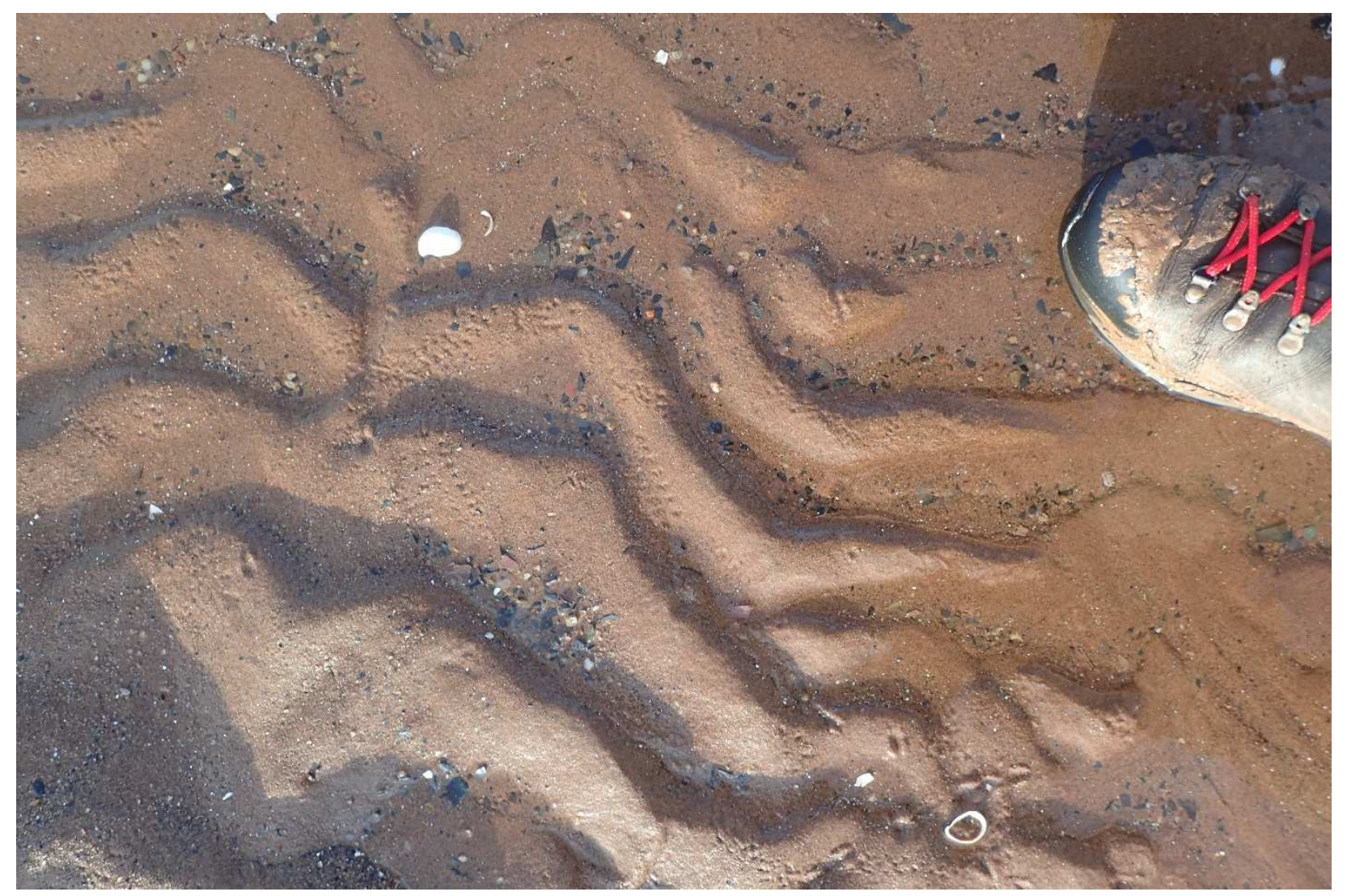

Figure S17. Preservation of footprint indents on damp ripple crests, but absent in waterlogged ripple troughs. Intertidal sands at low tide, Rainy Cove, Bay of Fundy, Nova

\section{Scotia, Canada.}

\section{COMPARISON WITH OTHER PALAEOZOIC ICHNOFAUNAS}

Classical multivariate cluster analysis was performed using Ward's method with a Euclidean similarity index in order to compare the ichnofaunal assemblage of the Wallowbarrow Tuff Formation with other Palaeozoic ichnofaunas. Analysis was performed using PAST (PAlaeontological STatistics) software (https://folk.uio.no/ohammer/past/). The known trace fossil assemblages from all formations grouped as Cambrian-Ordovician Coastal, Silurian Coastal, Silurian Alluvial and Lacustrine, Devonian Coastal and Devonian Alluvial and Lacustrine were used for comparison (utilizing ichnofaunal lists in Minter et al., 2016: see Table S6). While the Silurian and Devonian ichnofaunas grouped together in one cluster, the 
Wallowbarrow assemblage is more similar in composition to the limited arthropod trackway ichnofaunas of other Cambrian and Ordovician littoral successions.

\section{DATA TABLES}

Table S3. Measurements of individual traces on each trackway surface (see Table S1) (trace fossil type shown as $A=$ Diplichnites, $B=$ Diplopodichnus, $A B=$ Transitional forms).

\begin{tabular}{|c|c|c|c|c|c|c|}
\hline Surface & Trace \# & Distance & Length & Width & Sinuosity & $A / B ?$ \\
\hline$x$ & 1 & 92 & 93 & 6 & 1.01 & $A$ \\
\hline$x$ & 2 & 64 & 67 & 5 & 1.05 & $A$ \\
\hline$x$ & 3 & 48 & 48 & 5 & 1.00 & $A$ \\
\hline$A$ & 1 & 200 & 205 & 10 & 1.03 & $B$ \\
\hline$A$ & 2 & 315 & 323 & 10 & 1.02 & $B$ \\
\hline B & 1 & 173 & 237 & 5 & 1.37 & B \\
\hline$B$ & 2 & 240 & 247 & 5 & 1.03 & $A B$ \\
\hline B & 3 & 113 & 113 & 3 & 1.00 & B \\
\hline$B$ & 4 & 63 & 67 & 3 & 1.05 & $B$ \\
\hline$B$ & 5 & 25 & 25 & 4 & 1.00 & $A$ \\
\hline$B$ & 6 & 20 & 20 & 4 & 1.00 & $A$ \\
\hline B & 7 & 270 & 270 & 7 & 1.00 & A \\
\hline$B$ & 8 & 30 & 30 & 5 & 1.00 & $A$ \\
\hline$B$ & 9 & 45 & 45 & 9 & 1.00 & $A$ \\
\hline$B$ & 10 & 100 & 100 & 4 & 1.00 & $B$ \\
\hline B & 11 & 50 & 50 & 9 & 1.00 & $B$ \\
\hline$B$ & 12 & 200 & 200 & 5 & 1.00 & $B$ \\
\hline B & 13 & 40 & 40 & 5 & 1.00 & B \\
\hline$B$ & 14 & 35 & 35 & 8 & 1.00 & A \\
\hline B & 15 & 40 & 40 & 5 & 1.00 & A \\
\hline B & 16 & 30 & 30 & 5 & 1.00 & A \\
\hline B & 17 & 130 & 130 & 4 & 1.00 & $B$ \\
\hline
\end{tabular}




\begin{tabular}{|c|c|c|c|c|c|c|}
\hline B & 18 & 195 & 195 & 5 & 1.00 & B \\
\hline$B$ & 19 & 300 & 370 & 6 & 1.23 & B \\
\hline C1 & 1 & 44 & 47 & 4 & 1.05 & B \\
\hline C1 & 2 & 18 & 27 & 4 & 1.50 & $B$ \\
\hline C1 & 3 & 71 & 111 & 4 & 1.56 & B \\
\hline C1 & 4 & 27 & 27 & 4 & 1.00 & B \\
\hline C1 & 5 & 91 & 91 & 4 & 1.00 & B \\
\hline $\mathrm{C} 1$ & 6 & 40 & 42 & 4 & 1.06 & $B$ \\
\hline $\mathrm{C} 1$ & 7 & 38 & 120 & 4 & 3.18 & $B$ \\
\hline $\mathrm{C} 1$ & 8 & 18 & 18 & 4 & 1.00 & $B$ \\
\hline C1 & 9 & 22 & 24 & 4 & 1.10 & $B$ \\
\hline C1 & 10 & 62 & 64 & 6 & 1.04 & B \\
\hline C1 & 11 & 69 & 156 & 4 & 2.26 & $B$ \\
\hline C1 & 12 & 24 & 29 & 4 & 1.18 & $B$ \\
\hline C1 & 13 & 67 & 96 & 4 & 1.43 & B \\
\hline C1 & 14 & 64 & 64 & 4 & 1.00 & $B$ \\
\hline $\mathrm{C} 1$ & 15 & 22 & 31 & 4 & 1.40 & $B$ \\
\hline $\mathrm{C} 1$ & 16 & 44 & 44 & 4 & 1.00 & $B$ \\
\hline C1 & 17 & 151 & 242 & 4 & 1.60 & $A B$ \\
\hline $\mathrm{C} 1$ & 18 & 29 & 29 & 4 & 1.00 & $A$ \\
\hline C1 & 19 & 196 & 216 & 4 & 1.10 & $B$ \\
\hline C1 & 20 & 27 & 27 & 4 & 1.00 & B \\
\hline $\mathrm{C} 1$ & 21 & 38 & 120 & 4 & 3.18 & $A B$ \\
\hline $\mathrm{C} 1$ & 22 & 93 & 436 & 6 & 4.67 & $B$ \\
\hline $\mathrm{C} 1$ & 23 & 47 & 122 & 4 & 2.62 & $B$ \\
\hline $\mathrm{C} 1$ & 24 & 33 & 33 & 4 & 1.00 & $B$ \\
\hline $\mathrm{C} 1$ & 25 & 25 & 25 & 4 & 1.00 & $A$ \\
\hline C1 & 26 & 153 & 186 & 7 & 1.22 & A \\
\hline $\mathrm{C} 1$ & 27 & 322 & 333 & 7 & 1.03 & $B$ \\
\hline C1 & 28 & 64 & 422 & 6 & 6.61 & $A B$ \\
\hline
\end{tabular}




\begin{tabular}{|c|c|c|c|c|c|c|}
\hline C1 & 29 & 125 & 272 & 6 & 2.18 & $B$ \\
\hline C1 & 30 & 328 & 333 & 6 & 1.02 & B \\
\hline $\mathrm{C} 1$ & 31 & 39 & 39 & 4 & 1.00 & $A$ \\
\hline $\mathrm{C} 2$ & 1 & 60 & 60 & 6 & 1.00 & $A$ \\
\hline $\mathrm{C} 2$ & 2 & 150 & 150 & 6 & 1.00 & $B$ \\
\hline $\mathrm{C} 2$ & 3 & 110 & 110 & 6 & 1.00 & $A B$ \\
\hline $\mathrm{C} 2$ & 4 & 110 & 110 & 8 & 1.00 & $B$ \\
\hline $\mathrm{C} 2$ & 5 & 115 & 115 & 4 & 1.00 & $A$ \\
\hline $\mathrm{C} 2$ & 6 & 50 & 50 & 7 & 1.00 & $B$ \\
\hline $\mathrm{C} 2$ & 7 & 65 & 65 & 9 & 1.00 & $A$ \\
\hline $\mathrm{C} 2$ & 8 & 95 & 95 & 8 & 1.00 & B \\
\hline $\mathrm{D}$ & 1 & 306 & 367 & 8 & 1.20 & B \\
\hline $\mathrm{D}$ & 2 & 300 & 316 & 8 & 1.05 & $B$ \\
\hline$D$ & 3 & 82 & 90 & 6 & 1.10 & B \\
\hline D & 4 & 167 & 282 & 8 & 1.68 & B \\
\hline$D$ & 5 & 102 & 106 & 8 & 1.04 & $B$ \\
\hline $\mathrm{D}$ & 6 & 65 & 67 & 7 & 1.03 & $B$ \\
\hline $\mathrm{D}$ & 7 & 190 & 198 & 8 & 1.04 & $B$ \\
\hline D & 8 & 104 & 106 & 8 & 1.02 & $B$ \\
\hline $\mathrm{D}$ & 9 & 144 & 184 & 9 & 1.28 & $B$ \\
\hline $\mathrm{D}$ & 10 & 249 & 256 & 4 & 1.03 & $B$ \\
\hline$D$ & 11 & 20 & 20 & 4 & 1.00 & $A$ \\
\hline $\mathrm{D}$ & 12 & 278 & 349 & 7 & 1.26 & $A B$ \\
\hline $\mathrm{D}$ & 13 & 58 & 58 & 7 & 1.00 & $B$ \\
\hline$D$ & 14 & 49 & 51 & 7 & 1.05 & $A B$ \\
\hline$D$ & 15 & 266 & 276 & 6 & 1.04 & $B$ \\
\hline$D$ & 16 & 230 & 244 & 4 & 1.06 & B \\
\hline D & 17 & 184 & 194 & 9 & 1.05 & $B$ \\
\hline $\mathrm{D}$ & 18 & 56 & 60 & 6 & 1.07 & $B$ \\
\hline$D$ & 19 & 60 & 60 & 6 & 1.00 & $A$ \\
\hline
\end{tabular}




\begin{tabular}{|c|c|c|c|c|c|c|}
\hline D & 20 & 156 & 232 & 6 & 1.49 & B \\
\hline$D$ & 21 & 136 & 140 & 6 & 1.03 & $B$ \\
\hline$D$ & 22 & 294 & 336 & 8 & 1.14 & $A B$ \\
\hline$D$ & 23 & 196 & 204 & 7 & 1.04 & $B$ \\
\hline$D$ & 24 & 85 & 91 & 6 & 1.08 & $B$ \\
\hline D & 25 & 121 & 123 & 5 & 1.02 & B \\
\hline$D$ & 26 & 96 & 96 & 10 & 1.00 & $B$ \\
\hline$D$ & 27 & 230 & 234 & 6 & 1.02 & $B$ \\
\hline$D$ & 28 & 96 & 98 & 4 & 1.02 & $A$ \\
\hline D & 29 & 30 & 30 & 5 & 1.00 & $A$ \\
\hline D & 30 & 13 & 13 & 4 & 1.00 & B \\
\hline$D$ & 31 & 31 & 31 & 5 & 1.00 & $A$ \\
\hline$D$ & 32 & 62 & 68 & 4 & 1.09 & $B$ \\
\hline$D$ & 33 & 64 & 67 & 4 & 1.05 & $A$ \\
\hline D & 34 & 41 & 43 & 4 & 1.07 & B \\
\hline D & 35 & 90 & 90 & 5 & 1.00 & B \\
\hline$D$ & 36 & 31 & 34 & 7 & 1.11 & $B$ \\
\hline$D$ & 37 & 498 & 568 & 10 & 1.14 & $B$ \\
\hline$D$ & 38 & 59 & 59 & 6 & 1.00 & $B$ \\
\hline$D$ & 39 & 54 & 76 & 5 & 1.41 & $A B$ \\
\hline$D$ & 40 & 34 & 34 & 4 & 1.00 & $B$ \\
\hline$D$ & 41 & 132 & 141 & 7 & 1.06 & $B$ \\
\hline$D$ & 42 & 25 & 25 & 3 & 1.00 & $A$ \\
\hline$D$ & 43 & 219 & 494 & 8 & 2.26 & $B$ \\
\hline$D$ & 44 & 502 & 727 & 8 & 1.45 & $B$ \\
\hline$D$ & 45 & 100 & 100 & 8 & 1.00 & $B$ \\
\hline D & 46 & 96 & 96 & 8 & 1.00 & $B$ \\
\hline D & 47 & 56 & 242 & 8 & 4.30 & $B$ \\
\hline$D$ & 48 & 52 & 60 & 7 & 1.16 & $B$ \\
\hline D & 49 & 46 & 48 & 10 & 1.05 & $B$ \\
\hline
\end{tabular}




\begin{tabular}{|c|c|c|c|c|c|c|}
\hline D & 50 & 58 & 58 & 4 & 1.00 & B \\
\hline$D$ & 51 & 75 & 75 & 11 & 1.00 & $B$ \\
\hline$D$ & 52 & 21 & 21 & 4 & 1.00 & $B$ \\
\hline D & 53 & 345 & 347 & 7 & 1.01 & $B$ \\
\hline$D$ & 54 & 145 & 161 & 6 & 1.11 & $A B$ \\
\hline D & 55 & 78 & 110 & 7 & 1.42 & B \\
\hline D & 56 & 106 & 106 & 12 & 1.00 & B \\
\hline$D$ & 57 & 8 & 8 & 4 & 1.00 & $B$ \\
\hline D & 58 & 104 & 113 & 5 & 1.08 & $B$ \\
\hline D & 59 & 29 & 29 & 6 & 1.00 & $B$ \\
\hline D & 60 & 233 & 235 & 15 & 1.01 & B \\
\hline$D$ & 61 & 177 & 183 & 6 & 1.04 & $B$ \\
\hline D & 62 & 21 & 21 & 5 & 1.00 & $A$ \\
\hline D & 63 & 112 & 129 & 5 & 1.16 & $B$ \\
\hline D & 64 & 82 & 84 & 7 & 1.02 & B \\
\hline D & 65 & 75 & 82 & 13 & 1.11 & B \\
\hline D & 66 & 39 & 41 & 7 & 1.05 & $B$ \\
\hline$D$ & 67 & 84 & 86 & 10 & 1.02 & $B$ \\
\hline D & 68 & 94 & 110 & 5 & 1.17 & B \\
\hline D & 69 & 278 & 316 & 8 & 1.14 & $B$ \\
\hline D & 70 & 16 & 18 & 6 & 1.13 & A \\
\hline D & 71 & 20 & 20 & 4 & 1.00 & A \\
\hline D & 72 & 192 & 204 & 5 & 1.06 & $A B$ \\
\hline D & 73 & 16 & 16 & 5 & 1.00 & A \\
\hline D & 74 & 22 & 22 & 4 & 1.00 & A \\
\hline$D$ & 75 & 37 & 43 & 5 & 1.17 & $A B$ \\
\hline D & 76 & 10 & 10 & 4 & 1.00 & A \\
\hline D & 77 & 63 & 65 & 7 & 1.03 & B \\
\hline D & 78 & 129 & 180 & 7 & 1.40 & B \\
\hline D & 79 & 80 & 314 & 8 & 3.95 & $B$ \\
\hline
\end{tabular}




\begin{tabular}{|c|c|c|c|c|c|c|}
\hline D & 80 & 73 & 82 & 4 & 1.11 & A \\
\hline D & 81 & 59 & 59 & 5 & 1.00 & $A$ \\
\hline$D$ & 82 & 69 & 69 & 4 & 1.00 & $A$ \\
\hline$D$ & 83 & 176 & 180 & 4 & 1.02 & $A$ \\
\hline D & 84 & 167 & 176 & 5 & 1.05 & $A$ \\
\hline$D$ & 85 & 15 & 15 & 6 & 1.00 & $A$ \\
\hline$D$ & 86 & 46 & 46 & 3 & 1.00 & $A$ \\
\hline$D$ & 87 & 10 & 10 & 6 & 1.00 & $A$ \\
\hline$D$ & 88 & 17 & 17 & 5 & 1.00 & $A$ \\
\hline$D$ & 89 & 25 & 25 & 5 & 1.00 & A \\
\hline$D$ & 90 & 58 & 100 & 10 & 1.74 & B \\
\hline$D$ & 91 & 45 & 45 & 10 & 1.00 & B \\
\hline$D$ & 92 & 48 & 48 & 5 & 1.00 & $A$ \\
\hline$D$ & 93 & 119 & 119 & 8 & 1.00 & B \\
\hline$D$ & 94 & 260 & 983 & 7 & 3.78 & $B$ \\
\hline$D$ & 95 & 67 & 121 & 5 & 1.81 & $B$ \\
\hline$D$ & 96 & 25 & 25 & 4 & 1.00 & $A$ \\
\hline$D$ & 97 & 70 & 77 & 4 & 1.10 & $B$ \\
\hline$D$ & 98 & 144 & 144 & 7 & 1.00 & $B$ \\
\hline
\end{tabular}

Table S4. Measurements of looping in fully self-crossing Diplopidichnus trackways.

\begin{tabular}{|c|c|c|c|}
\hline Surface & $\begin{array}{c}\text { Loop } \\
\text { diameter }\end{array}$ & $\begin{array}{c}\text { Track } \\
\text { width }\end{array}$ & D/W \\
\hline C1 & 33 & 6 & 5.6 \\
\hline C1 & 44 & 6 & 7.4 \\
\hline C1 & 33 & 6 & 5.6 \\
\hline C1 & 16 & 6 & 2.6 \\
\hline C1 & 24 & 4 & 6.1 \\
\hline C1 & 29 & 4 & 7.2 \\
\hline C1 & 103 & 6 & 17.1 \\
\hline
\end{tabular}




\begin{tabular}{|c|c|c|c|}
\hline $\mathrm{C} 1$ & 128 & 6 & 21.3 \\
\hline $\mathrm{D}$ & 69 & 8 & 8.6 \\
\hline $\mathrm{D}$ & 96 & 8 & 12.0 \\
\hline $\mathrm{D}$ & 65 & 8 & 8.2 \\
\hline $\mathrm{D}$ & 102 & 8 & 12.8 \\
\hline $\mathrm{D}$ & 71 & 7 & 10.1 \\
\hline $\mathrm{D}$ & 56 & 7 & 8.0 \\
\hline $\mathrm{D}$ & 92 & 7 & 13.1 \\
\hline
\end{tabular}

Table S5. Average trackway dimensions.

\begin{tabular}{|c|c|c|c|c|c|}
\hline & & $\begin{array}{c}\text { Av. } \\
\text { Sinuosity }\end{array}$ & $\begin{array}{c}\text { Av. } \\
\text { Length }\end{array}$ & $\begin{array}{c}\text { Av. } \\
\text { Width }\end{array}$ & Number \\
\hline Diplichnites & A & 1.02 & 56 & 5 & 43 \\
\hline Diplopodichnus & B & 1.28 & 153 & 7 & 106 \\
\hline Transitional & AB & 1.80 & 197 & 6 & 12 \\
\hline
\end{tabular}

Table S6. Data matrix compiled from Minter et al. (2016) and used for multivariate cluster analysis. 0 indicates absence and 1 indicates presence of a particular trace from the facies/age combination shown.

\begin{tabular}{|l|c|c|c|c|c|c|}
\hline & $\begin{array}{l}\text { C-0. } \\
\text { Coastal }\end{array}$ & BvG & S. Coastal & S. Alluvial & D. Coastal & D. Alluvial \\
\hline Diplichnites & 1 & 1 & 1 & 1 & 1 & 1 \\
\hline Protichnites & 1 & 0 & 1 & 0 & 0 & 1 \\
\hline Diplopodichnus & 1 & 1 & 0 & 1 & 1 & 1 \\
\hline Palmichnium & 1 & 0 & 1 & 1 & 1 & 1 \\
\hline Skolithos & 0 & 0 & 1 & 1 & 1 & 1 \\
\hline Diplocraterion & 0 & 0 & 1 & 0 & 1 & 1 \\
\hline Psammichnites & 0 & 0 & 1 & 0 & 0 & 0 \\
\hline Daedalus & 0 & 0 & 1 & 0 & 0 & 0 \\
\hline Palaeophycus & 0 & 0 & 1 & 1 & 0 & 1 \\
\hline
\end{tabular}




\begin{tabular}{|c|c|c|c|c|c|c|}
\hline Arenicolites & 1 & 0 & 1 & 1 & 1 & 1 \\
\hline Polarichnus & 0 & 0 & 1 & 1 & 0 & 0 \\
\hline Arthraria & 0 & 0 & 1 & 0 & 0 & 0 \\
\hline Bergaueria & 0 & 0 & 1 & 0 & 0 & 0 \\
\hline Cochlichnus & 0 & 0 & 1 & 1 & 0 & 1 \\
\hline Gordia & 0 & 0 & 1 & 0 & 0 & 0 \\
\hline Cruziana & 0 & 0 & 1 & 1 & 1 & 1 \\
\hline Monomorphichnus & 0 & 0 & 1 & 1 & 1 & 0 \\
\hline Helicodromites & 0 & 0 & 1 & 0 & 0 & 0 \\
\hline Chondrites & 0 & 0 & 1 & 0 & 1 & 0 \\
\hline Protovirgularia & 0 & 0 & 1 & 0 & 1 & 0 \\
\hline Petalichnus & 0 & 0 & 1 & 0 & 1 & 0 \\
\hline Beaconites & 0 & 0 & 1 & 1 & 1 & 1 \\
\hline Syncoprulus & 0 & 0 & 1 & 0 & 0 & 0 \\
\hline Didymaulichnus & 0 & 0 & 1 & 1 & 1 & 0 \\
\hline Rhizocorallium & 0 & 0 & 1 & 0 & 0 & 0 \\
\hline Heimdallia & 0 & 0 & 1 & 0 & 1 & 0 \\
\hline Didymauliponomos & 0 & 0 & 1 & 0 & 1 & 0 \\
\hline Helminthopsis & 0 & 0 & 1 & 0 & 1 & 0 \\
\hline Crescentichnus & 0 & 0 & 1 & 0 & 1 & 1 \\
\hline Taenidium & 0 & 0 & 1 & 0 & 1 & 1 \\
\hline Rusophycus & 0 & 0 & 1 & 1 & 1 & 1 \\
\hline Tumblagoodichnus & 0 & 0 & 1 & 0 & 0 & 1 \\
\hline Planolites & 0 & 0 & 1 & 1 & 1 & 1 \\
\hline Paleohelcura & 0 & 0 & 1 & 1 & 0 & 1 \\
\hline Siskemia & 0 & 0 & 1 & 0 & 0 & 1 \\
\hline Merostomichnites & 0 & 0 & 1 & 1 & 0 & 1 \\
\hline Oniscoidichnus & 0 & 0 & 1 & 0 & 0 & 0 \\
\hline Stiaria & 0 & 0 & 1 & 0 & 0 & 1 \\
\hline Steinsfjordichnus & 0 & 0 & 1 & 0 & 0 & 0 \\
\hline
\end{tabular}




\begin{tabular}{|c|c|c|c|c|c|c|}
\hline Scoyenia & 0 & 0 & 1 & 0 & 0 & 1 \\
\hline Striatichnium & 0 & 0 & 1 & 0 & 0 & 0 \\
\hline Spirophyton & 0 & 0 & 0 & 0 & 1 & 0 \\
\hline Teichichnus & 0 & 0 & 0 & 0 & 1 & 0 \\
\hline Lockeia & 0 & 0 & 0 & 0 & 1 & 0 \\
\hline Maculichna & 0 & 0 & 0 & 0 & 1 & 0 \\
\hline Asterosoma & 0 & 0 & 0 & 0 & 1 & 0 \\
\hline Lanicoidichna & 0 & 0 & 0 & 0 & 1 & 0 \\
\hline Agrichnium & 0 & 0 & 0 & 0 & 1 & 0 \\
\hline Treptichnus & 0 & 0 & 0 & 0 & 1 & 1 \\
\hline Lophoctenium & 0 & 0 & 0 & 0 & 1 & 0 \\
\hline Halopoa & 0 & 0 & 0 & 0 & 1 & 1 \\
\hline Svalbardichnus & 0 & 0 & 0 & 0 & 0 & 1 \\
\hline Striatichnium & 0 & 0 & 0 & 0 & 0 & 1 \\
\hline Stiallia & 0 & 0 & 0 & 0 & 0 & 1 \\
\hline Undichna & 0 & 0 & 0 & 0 & 0 & 1 \\
\hline Danstairia & 0 & 0 & 0 & 0 & 0 & 1 \\
\hline Keircallia & 0 & 0 & 0 & 0 & 0 & 1 \\
\hline Mitchellichnus & 0 & 0 & 0 & 0 & 0 & 1 \\
\hline Scolicia & 0 & 0 & 0 & 0 & 0 & 1 \\
\hline Mermia & 0 & 0 & 0 & 0 & 0 & 1 \\
\hline Asterichnus & 0 & 0 & 0 & 0 & 0 & 1 \\
\hline Bifungites & 0 & 0 & 0 & 0 & 1 & 0 \\
\hline Cylindricum & 0 & 0 & 0 & 0 & 1 & 0 \\
\hline Thalassinoides & 0 & 0 & 0 & 0 & 1 & 0 \\
\hline Gyrichnites & 0 & 0 & 0 & 0 & 0 & 1 \\
\hline Pustulichnus & 0 & 0 & 0 & 0 & 0 & 1 \\
\hline Entradichnus & 0 & 0 & 0 & 0 & 0 & 1 \\
\hline Ancorichnus & 0 & 0 & 0 & 0 & 0 & 1 \\
\hline Cornulatichnus & 0 & 0 & 0 & 0 & 0 & 1 \\
\hline
\end{tabular}




\begin{tabular}{|l|c|c|c|c|c|c|} 
Kouphichnium & 0 & 0 & 0 & 0 & 1 & 0 \\
\hline Nereites & 0 & 0 & 0 & 0 & 1 & 0 \\
\hline Total & 5 & 2 & 40 & 16 & 35 & 38 \\
\hline
\end{tabular}

\section{LARGER IMAGES OF PHOTOGRAPHS SHOWN IN FIGURES 2 AND 3}

Figure 2. Sedimentological characteristics of the trackway-bearing tuffs at Lum Pot [position on Figure 1C log or trackway surface in square brackets]. A) Furrowed grooves developed as overlying ash eroded down to a new semi-firm substrate, later traversed by Diplichnites and Diplopodichnus [Surface D]; B) Unconsolidated substrate revealed by reworking of tuff into bifurcating wave ripple marks. Surface hosts multiple short $(<15 \mathrm{~cm})$ trackways (not visible at this scale; locations starred) [Surface B]; C) Homogenous tuff with two vesicular horizons [20.7 m]; D) Pumice clasts (pink arrow) with similar-sized weathered out holes (yellow arrow), plan-view of exposed internal part of tuff bed [22.4 m]; E) Coarse layer of settled ash [1 cm below Surface C2]; F) Aggradational climbing wave ripples in cross section, indicating continuous ash deposition in agitated water [14.0 m]; G) Consolidated substrates revealed by vertical section through small brittle faults and fractures. Overlying $30 \mathrm{~cm}$ tuff bed has a horizontal upper bounding surface $[21.1 \mathrm{~m}]$; H) Bedding sags arising from impacting ejecta onto a wet substrate. Arrow points to Diplichnites (not visible at this scale) which descends over lip of crater and into sag [Surface C2]; I) Soft-sediment deformation arising from liquefaction of saturated, unconsolidated ash [13.6 m]; J) Banded tuff (B) passing vertically into large ball-and-pillow structures (BP) indicating instance of wholly unconsolidated and liquefied sediment [21.8 m]. Scale bars: $10 \mathrm{~cm}$ (black); $1 \mathrm{~cm}$ (red). See Appendix for larger photographs. 

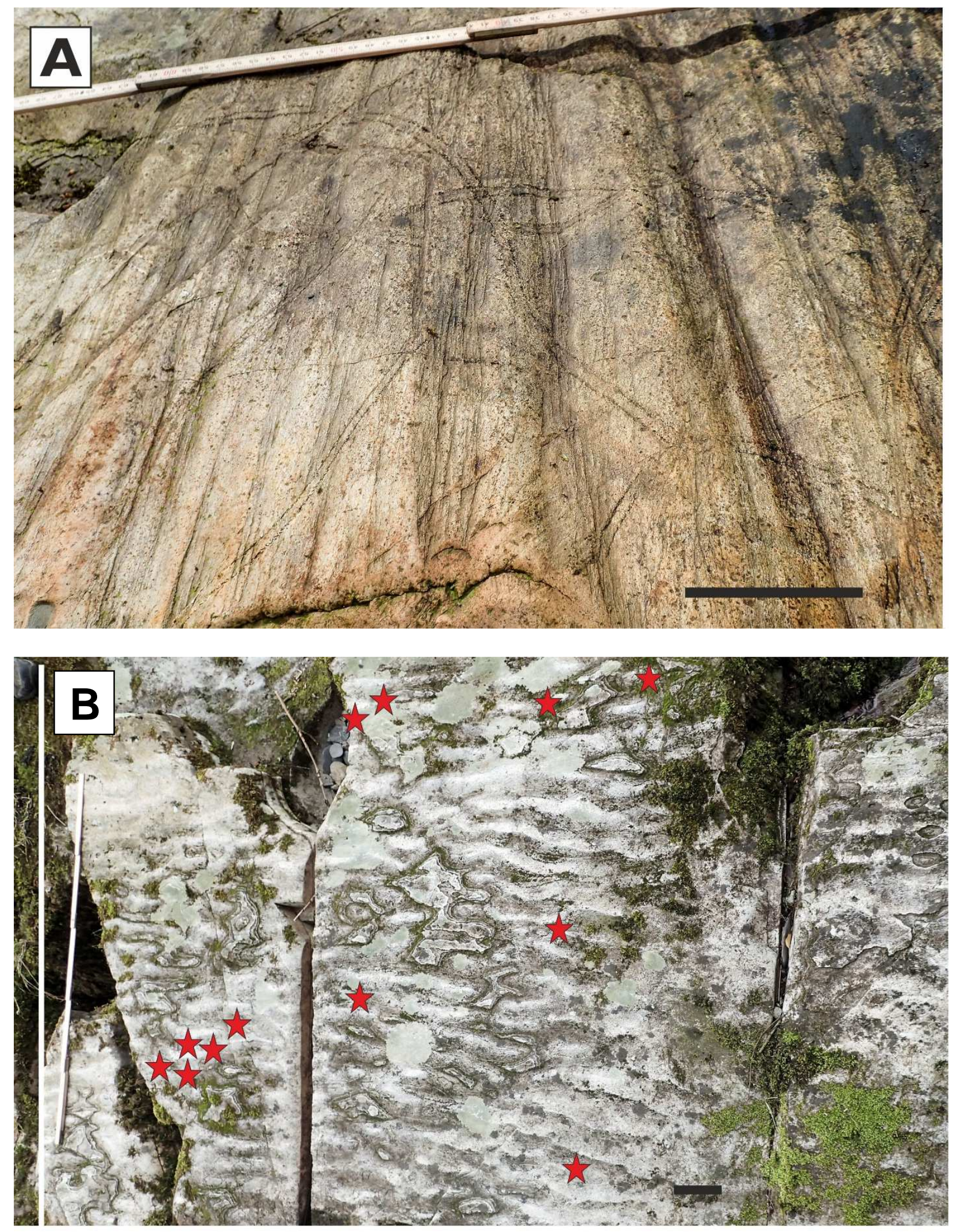

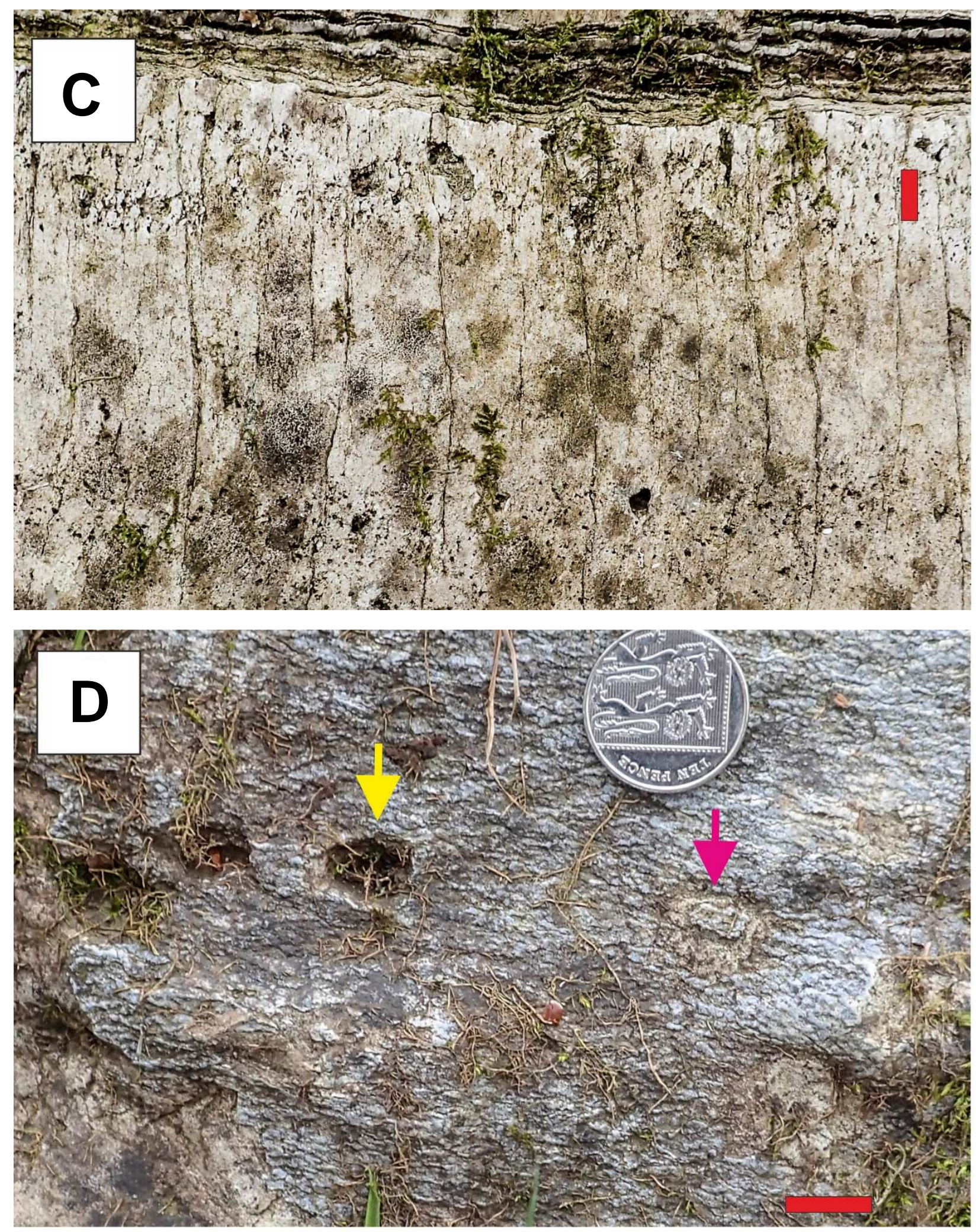

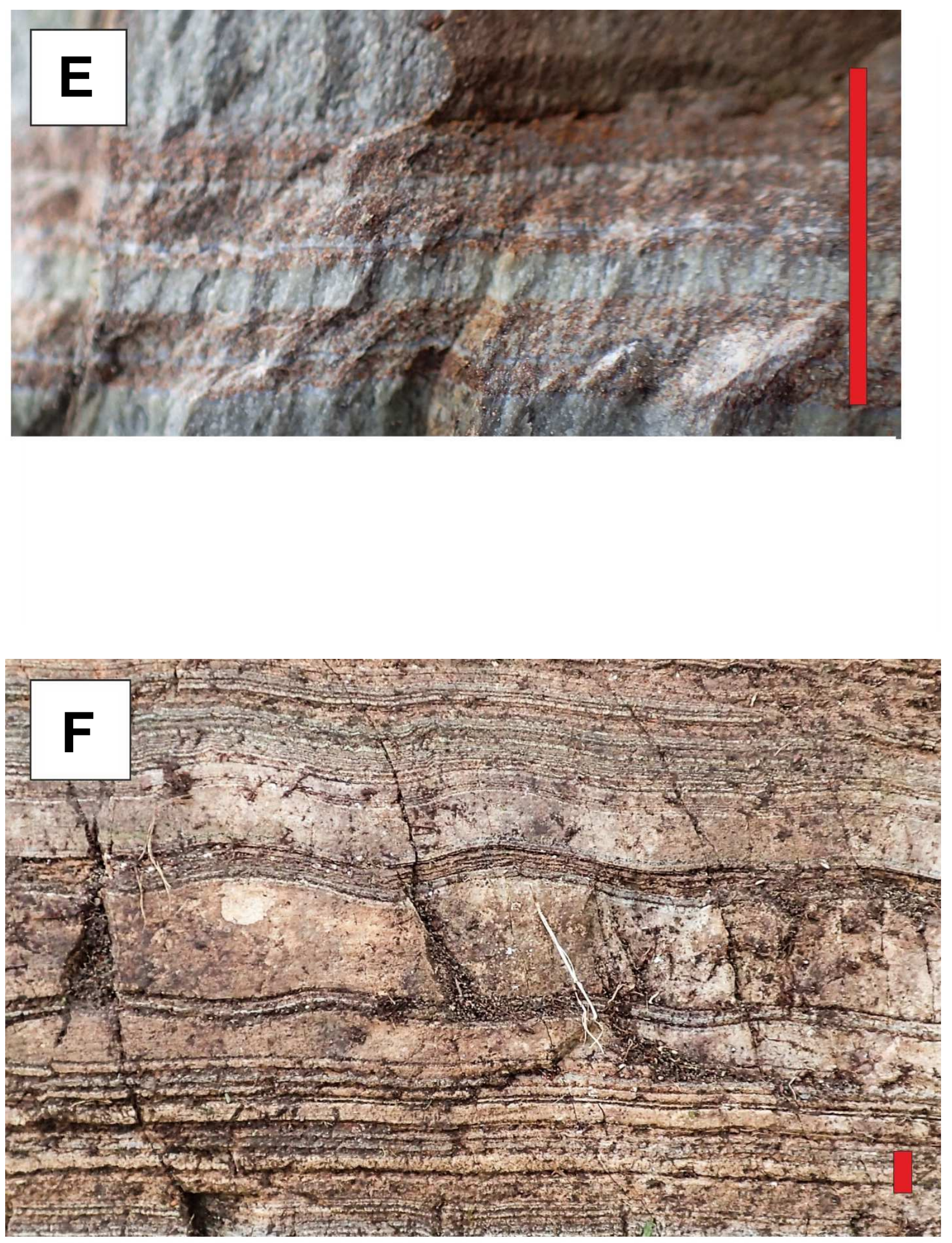

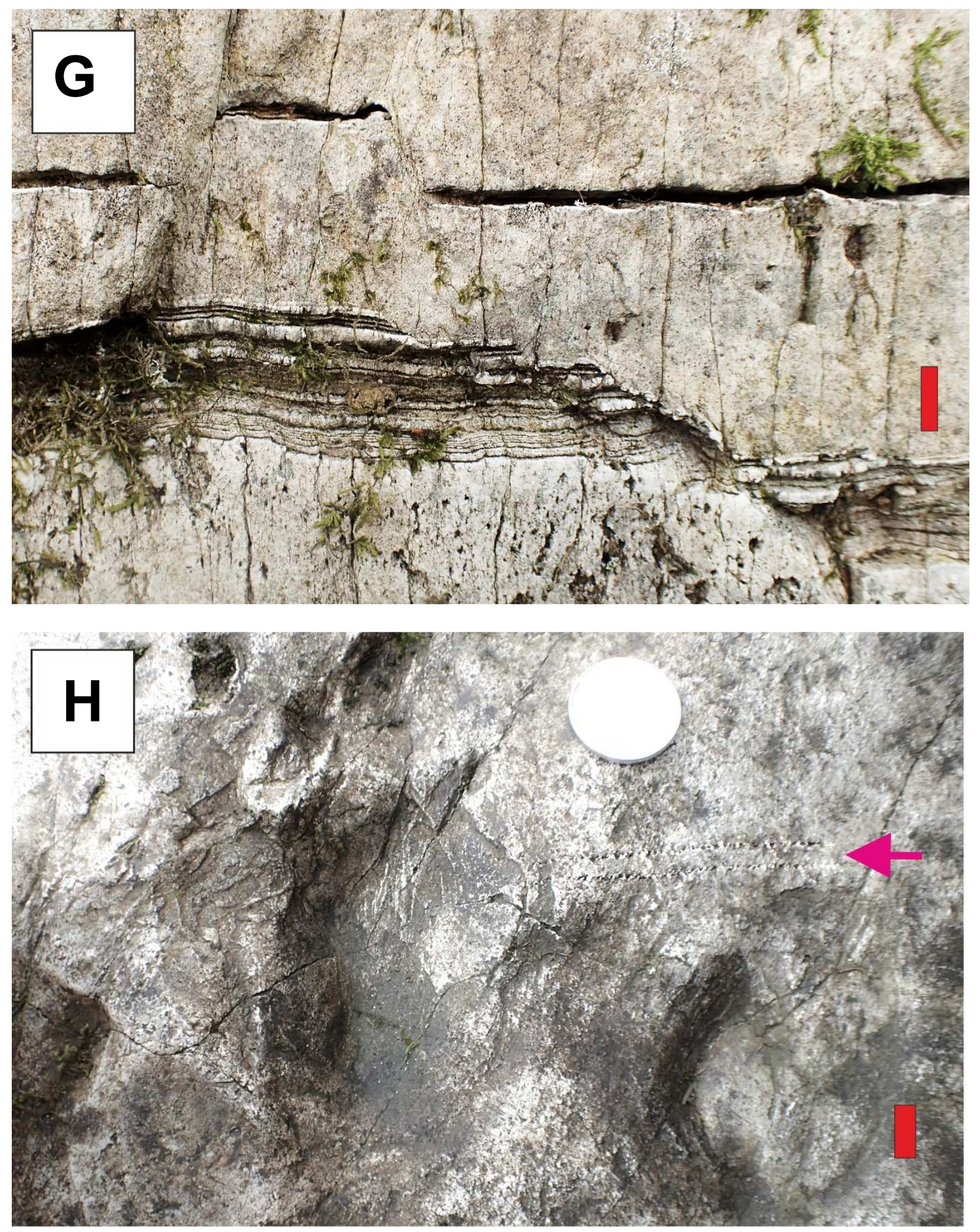

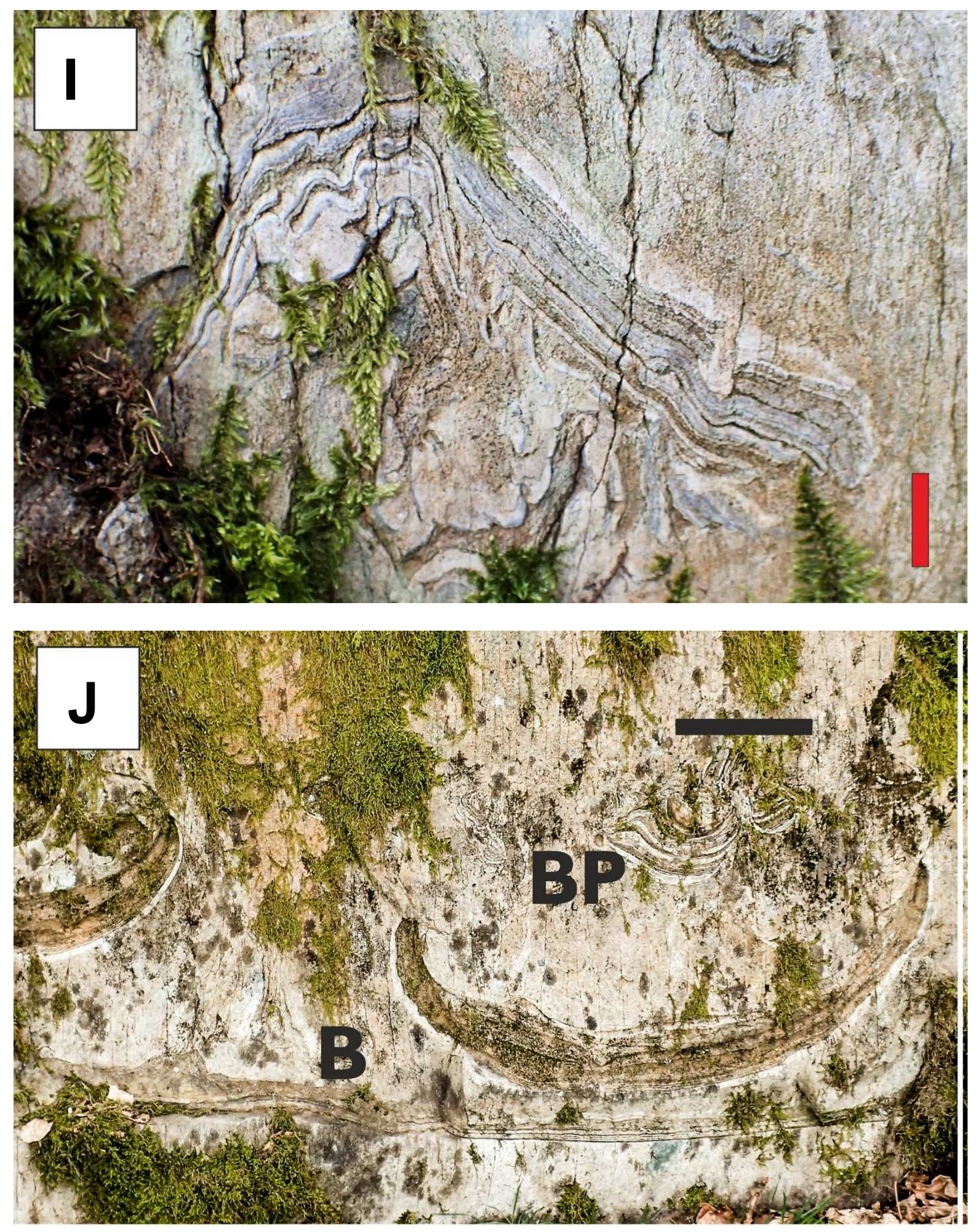

Figure 3. Distribution and form of trackways. B) Diplichnites restricted to ripple crests on Surface B, sketch shows measured transect of surface topography and distribution of trackways 
in pink; D) Diplopodichnus following microtopography of furrowed Surface D, with sketch as in Figure 3C; F) Evidence for probing behaviour at a curve in a Diplichnites trackway [Surface D]; G) Planview of a microfault scarp (top and bottom highlighted in blue) showing Diplichnites passing over scarp lip from left, and rejoining lower foot of scarp at a distance as tracemaker stepped downwards [Surface D]; H) Transition from Diplichnites to Diplopodichnus along same trackway [Surface D].
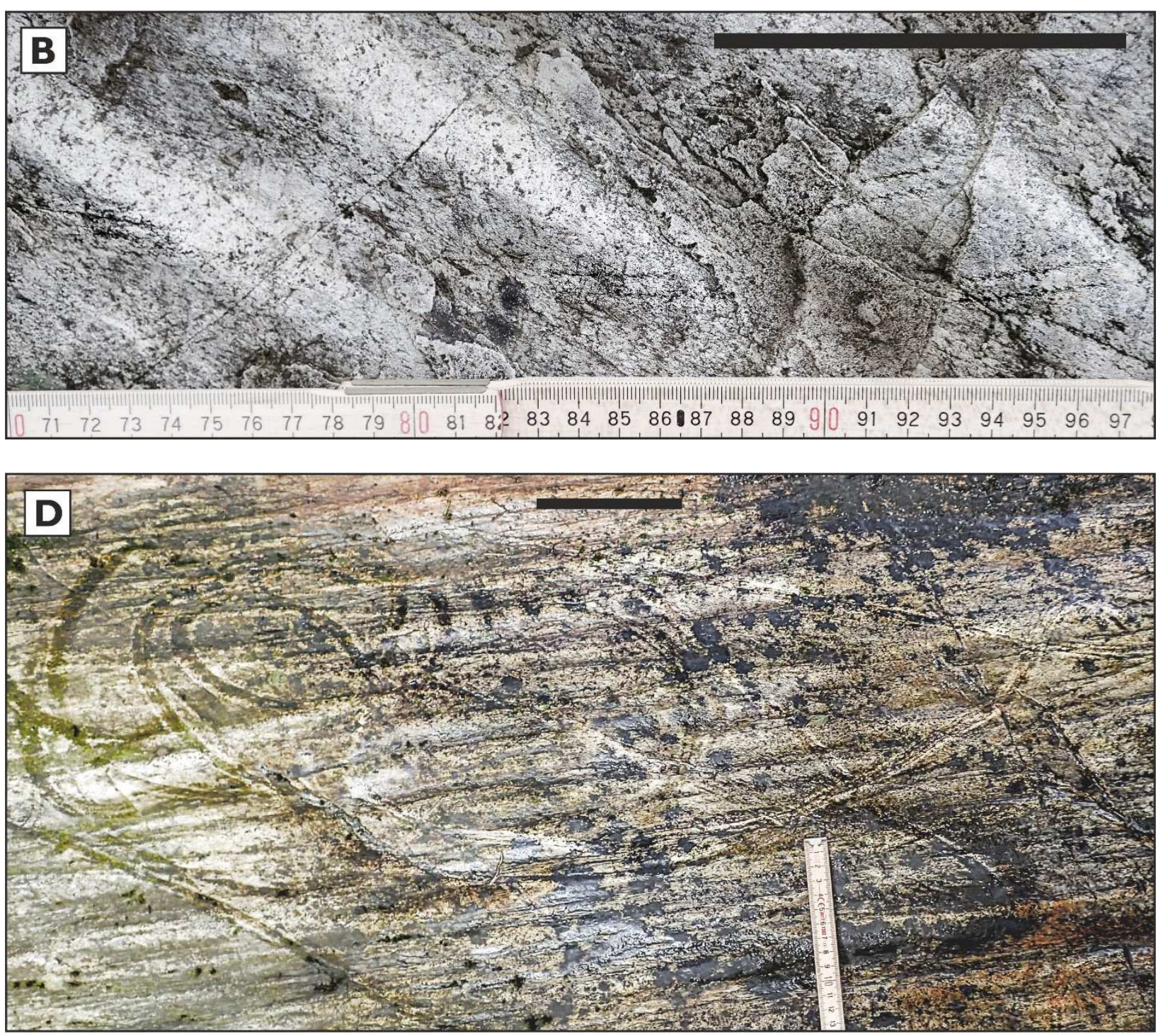


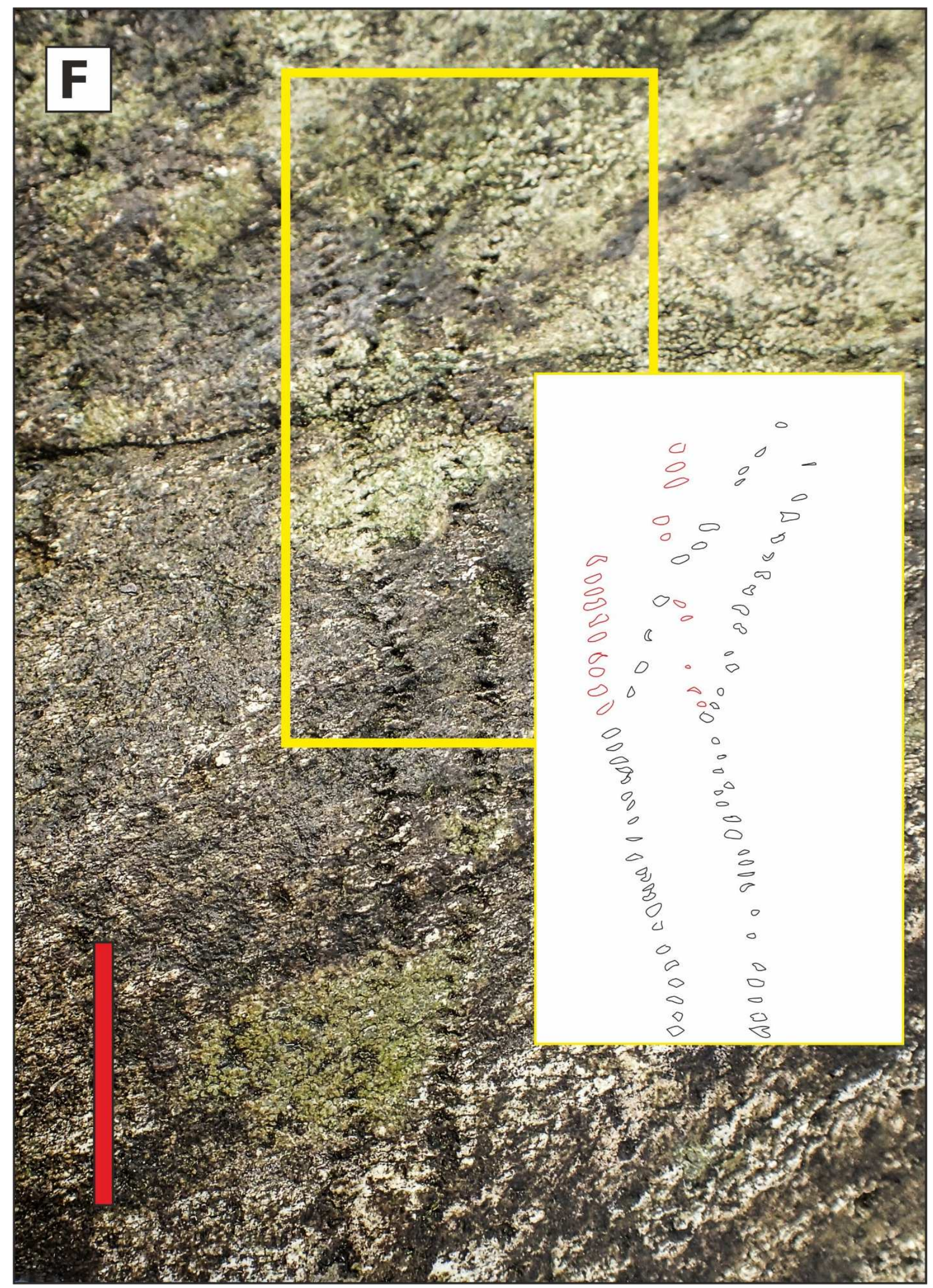



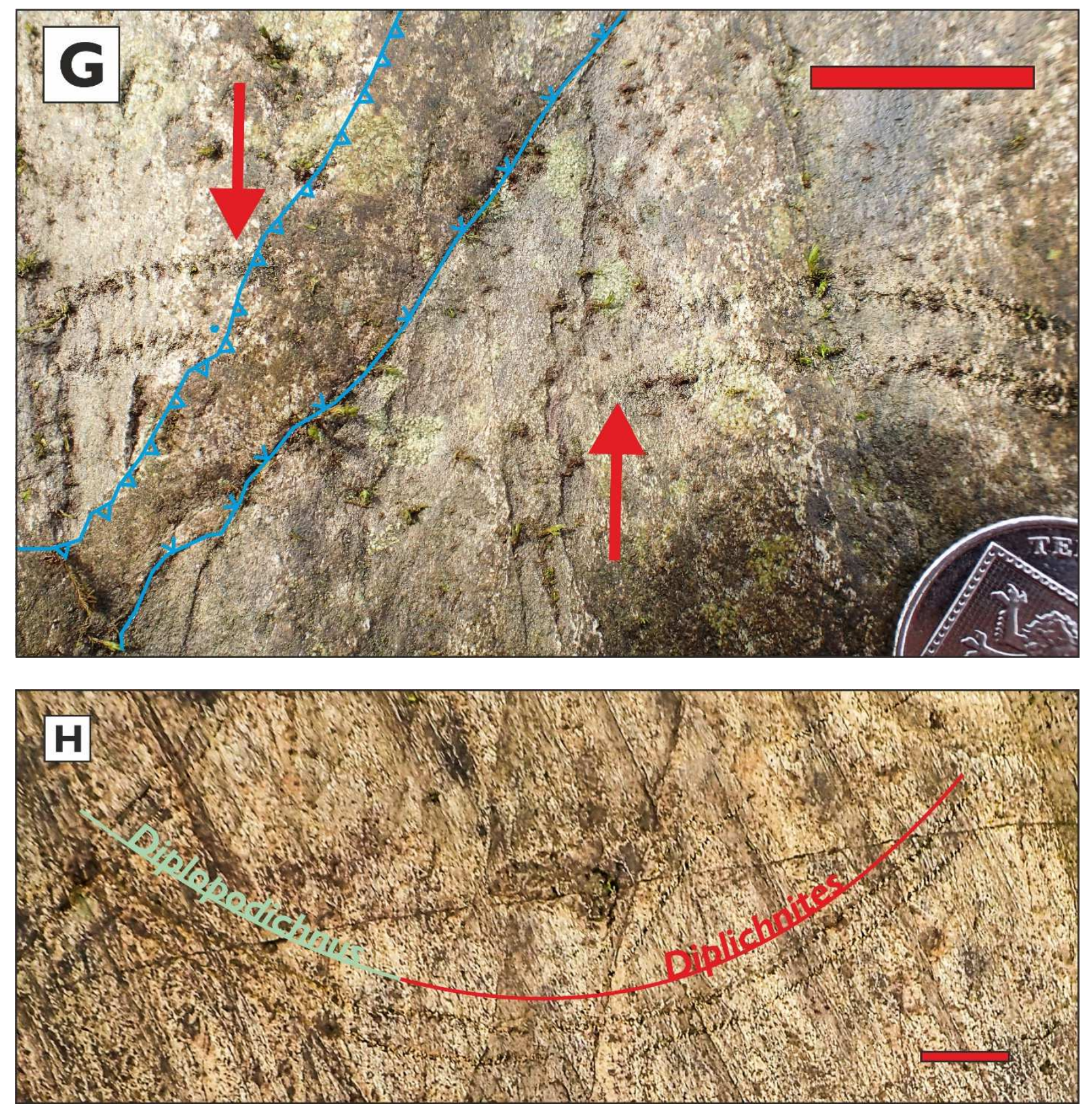